\title{
Dynamic of Land Use/Cover Change and Carbon Emission in Buol District, Indonesia
}

Chandra Irawadi Wijaya, Subekti Rahayu, Arif Prasetyo and Elissa Dwiyanti 



\section{Dynamics of Land Use/Cover Change and Carbon Emission in Buol District, Indonesia}

Chandra Irawadi Wijaya, Subekti Rahayu, Arif Prasetyo and Elissa Dwiyanti

Working Paper No. 214 


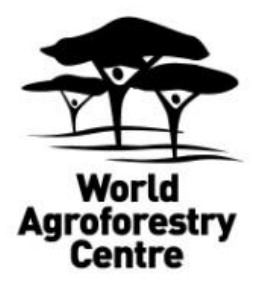

\section{Correct citation:}

Wijaya C, Rahayu S, Prasetyo A, Dwiyanti E. 2015. Dynamics of Land Use/Cover Change and Carbon Emission in Buol District, Indonesia. Working Paper no. 214. Bogor, Indonesia. World Agroforestry Centre (ICRAF) Southeast Asia Regional Program. 19p. DOI: http://dx.doi.org/10.5716/WP15725.PDF

Titles in the Working Paper Series aim to disseminate interim results on agroforestry research and practices and stimulate feedback from the scientific community. Other publication series from the World Agroforestry Centre include: Technical Manuals, Occasional Papers and the Trees for Change Series.

Published by the World Agroforestry Centre (ICRAF)

Southeast Asia Regional Program

PO Box 161, Bogor 16001

Indonesia

Tel: +622518625415

Fax: +62 2518625416

Email: icraf-indonesia@cgiar.org

Website: http://www.worldagroforestry.org/regions/southeast_asia

(C) World Agroforestry Centre 2015

Working Paper 214

\section{Photos:}

The views expressed in this publication are those of the author(s) and not necessarily those of the World Agroforestry Centre.

Articles appearing in this publication may be quoted or reproduced without charge, provided the source is acknowledged.

All images remain the sole property of their source and may not be used for any purpose without written permission of the source. 


\section{About the authors}

Chandra Irawadi Wijaya is a Geographic Information System (GIS) Specialist at the World Agroforestry Centre. His main areas of interest include forestry, forest resources conservation, natural resources management, land use/cover changes modeling, drivers of land use/cover changes, land use planning, payment/rewards for environmental services, hydrological modelling, and spatial database. He has a master degree in Information Technology for Natural Resource Management from Bogor Agriculture University, and a bachelor degree in Forest Resources Conservation from the same university. He has extensive experience in training local and national government bodies on GIS and information system for sustainable land development, as well as providing technical assistance to develop land use planning for low emission development strategies.

Contact: c.wijaya@cgiar.org

Subekti Rahayu is a Biodiversity and Carbon Stock Specialist at the World Agroforestry Centre. Her main area of interest include biodiversity conservation, ecological restoration, forest ecology, bioindicators and agroforest ecology. Currently she is on writing her $\mathrm{PhD}$ thesis on ecological restoration strategies of Samboja Forest Research, East Kalimantan, and she has a master degree in the same major of Tropical Biodiversity Conservation for Bogor Agriculture University. She hold a bachelors degree from the same university in a major of Plants Protection. She has an experience on carbon stock measurement at plot level since 1998 and deliver the training on carbon stock measurement for various institutions in Indonesia, as well as for local community in Indonesia and Vietnam since 2002

Contact: s.rahayu@cgiar.org

Arif Prasetyo is a master degree student of Natural Resource Management in Bogor Agricultural University. He hold a bachelor degree in Forest Resources Conservation and Ecotourism from the same university. His main areas of interest include forestry, forest resources conservation, ecology, spatial analysis and modelling, and environmental impact assessment. Currently, he provides consultancy work at Center for Biodiversity and Tropical Forest Rehabilitation (BIOREF) as Spatial Analysis and Land Use Planning Specialist. He has an experience in training forestry agencies on GIS and remote sensing, as well as providing technical assistance to develop Mangrove Information Centre (MIC) in Indramayu District, a collaboration work of Bogor Agriculture University and Ministry of Environment and Forestry.

Contact: arifprasetyo98@yahoo.com

Elissa Dwiyanti is a Remote Sensing and Geographic Information System (RSGIS) Assistant at the World Agroforestry Centre. Her main areas of interest include land use/cover changes analysis, drivers of land use/cover changes, and hydrological modeling. She has a bachelor degree in Soil Science from Bogor Agriculture University. She has experience in analyzing land use/cover changes over Indonesia regions, as well as providing technical assistance to develop land use planning for multiple environmental services.

Contact: e.dwiyanti@cgiar.org 


\section{Abstract}

The land-based sector in Buol District is the main source of livelihood for the community and therefore the trade-off between land provisions for developing its land-based sectors and improving ability of the landscape to store carbon stock is unavoidable. To support the local government of Buol District in formulating scenarios of land use planning towards low-emission development, this study resulted in analysis of land use/cover changes dynamic during 1996-2014, measurement carbon stock at plot level, and estimation of carbon emission at landscape level. This study also simulated the projection of carbon emission for the next 25 years based on the "business-as-usual" scenario.

Findings revealed that Forest, as the biggest carbon pool, was the main origin of the extensive development of Oil Palm Plantation and Complex Agroforestry as well as intermediate land uses/covers in the last two decades in Buol District. The carbon emission emitted by Forest transition to Oil Palm Plantation was seven times larger than Forest to Complex Agroforestry, even the total area of conversion from Forest to Oil Palm Plantation only 1.5 times larger than the conversion from Forest to Complex Agroforestry. Furthermore, deforestation and forest degradation activities contributed 77.6\% of total net emission in Buol District during 2009-2014. The BAU projection for the next 25 years increased carbon emission as of 3.5 times than the baseline period (2009-2014). Under the land use planning for low emission development strategy, the study suggest four major activities in Buol District that may balance carbon emission and sequestration, while maintaining economic growth of the district. To ensure commitment of stakeholders in implementing this strategy, the local government should integrate the strategy into District Development Plan and District Spatial Plan, so that the implementation can also be monitored and evaluated as part of the district agenda.

\section{Keywords}

Land use/cover changes, trajectories, deforestation, forest degradation, carbon emission, land use planning for low emission development strategy 


\section{Acknowledgements}

This working paper is the preliminary synthesis of the research activities undertaken during the first year of Smart Tree-Invest project in Buol District, funded by the International Fund for Agricultural Development (IFAD) and implemented by the World Agroforestry Centre (ICRAF) Southeast Asia Regional Program. 


\section{Contents}

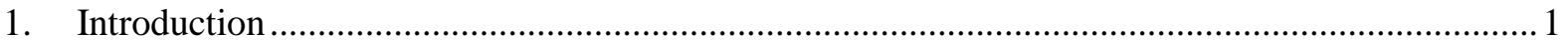

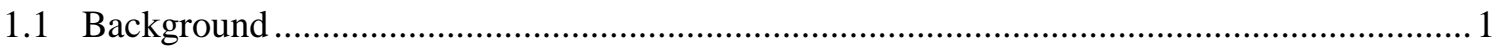

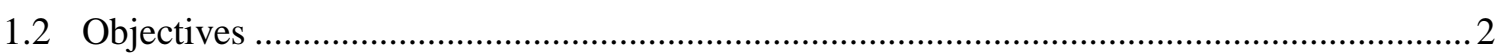

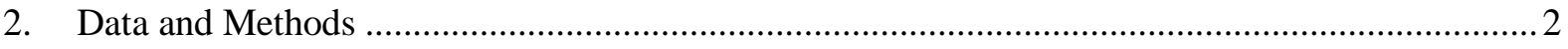

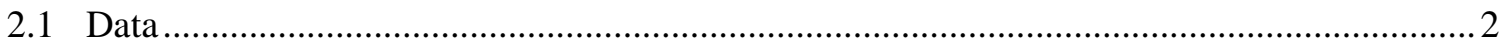

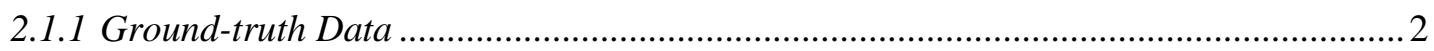

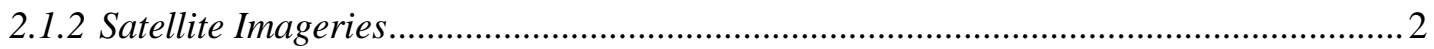

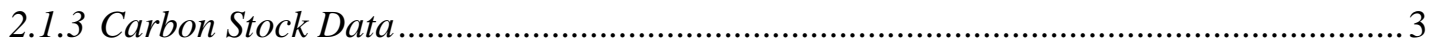

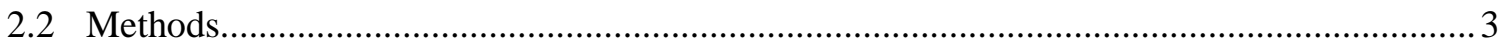

2.2.1 Analysis of Land Use/Cover Changes and Trajectories .............................................. 3

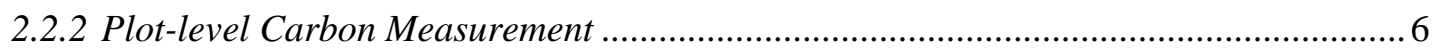

2.2.3 Landscape-level Carbon Emission Estimation ............................................................ 7

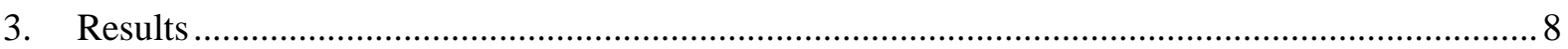

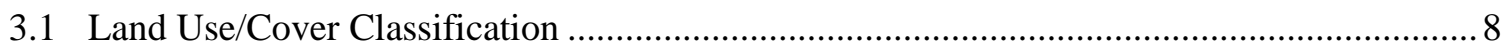

3.2 Land Use/Cover Changes and Trajectories........................................................................ 10

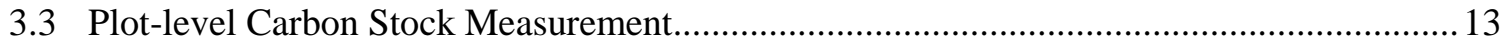

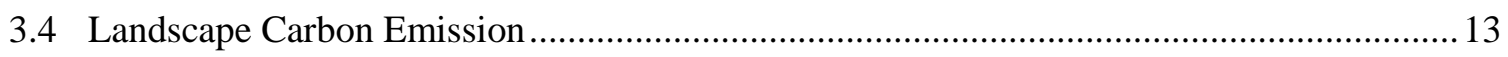

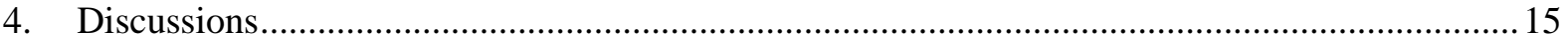

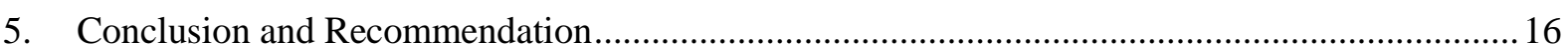




\section{List of figures}

Figure 1. Location of Buol District, Central Sulawesi ................................................................. 1

Figure 2. Analysis of Land Use/Cover Change and Trajectories (ALUCT) framework (Dewi and

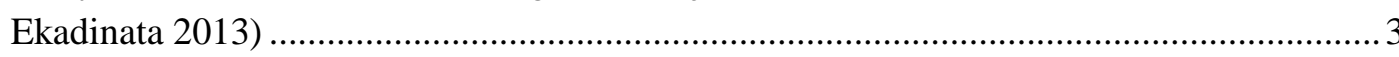

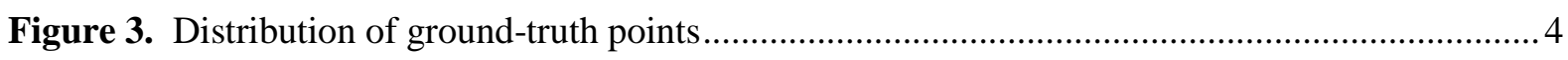

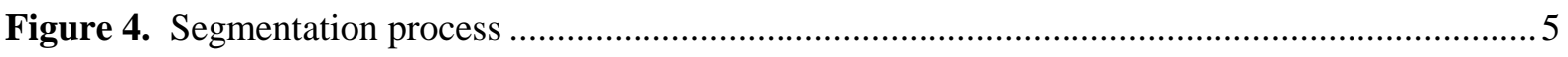

Figure 5. Illustration of Error Matrix and Mathematical Expression for Accuracy Assessment

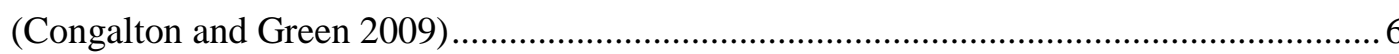

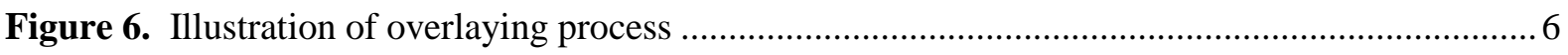

Figure 7. Diagram of nested plot for $\mathrm{C}$ stock measurement (Hairiah et al 2011) ................................

Figure 8. Landscape-level Carbon Emission Calculation (Dewi et al 2011) ...................................... 7

Figure 9. Hierarchal land use/cover classification scheme applied in Buol District........................... 8

Figure 10. Figure 10. Time-series of land use/cover maps of Buol District ...................................... 9

Figure 11. Proportion of land use/cover in Buol District during 1996 - 2014................................... 11

Figure 12. Major land use/cover trajectories in Buol District........................................................ 12

Figure 13. Annual carbon emission and the contribution of each land designation in Buol District

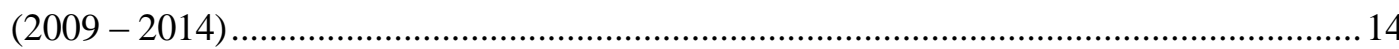

Figure 14. Contributions of land use/cover conversions to carbon emission in Buol District (20092014)

Figure 15. The projection of carbon emission for the next 25 years using the "business-as-usual" scenario

\section{List of tables}

Table 1. Land use/cover types in Buol District during 1996 - 2014 .................................... 10

Table 2. Land use/cover types and its carbon stock used in Buol District ............................. 13 


\section{List of Abbreviations \& Acronyms}

ALUCT Analysis of Land-Use/cover Changes and Trajectories

APL

Areal Penggunaan Lain (Other Land Uses)

ATCOR

Atmospheric and Topographic Correction for Satellite Imagery

BAU

Business-as-usual

BIG

Badan Informasi Geospasial (Geospatial Information Agency)

ETM+

FGD

Enhanced Thematic Mapper Plus

GHG

Focus Group Discussion

GPS

Green House Gases

HCS

Global Positioning System

$\mathrm{HCV}$

High Carbon Stock

HOBC

High Conservation Value

HP

Hierarchal object-based classification

HPK

Hutan Produksi Tetap (Production Forest)

HPT

Hutan Produksi Konversi (Convertible Production Forest)

ICRAF

Hutan Produksi Terbatas (Limited Production Forest)

IFAD

World Agroforestry Centre / international Centre for Research in Agroforestry

HD

International Fund for Agricultural Development

LCDM Landsat Data Continuity Mission

$\mathrm{LD}$

Low Density

LOF

Logged-over Forest

LUS

Land Use System

LUWES Land Use Planning for Low Emission Development Strategy

masl

meters above sea level

OBIA

Objet-based Image Analysis

OLI Operational Land Imager

RaCSA Rapid Carbon Stock Appraisal

REDD Reducing Emission from Deforestration and Forest Degradation

SLC-OFF Scan Line Corrector Off

TBS

Tree-based System 


\section{Introduction}

\subsection{Background}

Buol District is located in the northern part of Central Sulawesi Province, which stretches from $120^{\circ} 50^{\prime} 32.17^{\prime \prime}$ to $122^{\circ} 11^{\prime} 43.96 "$ East and between $0^{\circ} 40^{\prime} 32.50^{\prime \prime}$ to $1^{\circ} 18^{\prime} 45.93 "$ North. Located at an altitude of 0-1,000 meters above sea level (masl), the district borders Gorontalo Province to the west, Toli-toli District to the east, Celebes Sea to the north, and Parigi Moutong District to the south. The district covers a total area of 385,708 hectares (ha) with approximately two-thirds of the area comprising hills with steep and very steep slopes. The plain area is located downstream in the northern and central part of the district.

The population of Buol District was 132,330 in 2010, and the estimation in 2014 was about 145,889 (BPS Kabupaten Buol 2015). Approximately 43\% of Buol's population in 2014 comprised laborers who mainly worked in land-based sectors, such as agriculture, livestock, forestry, plantation and mining. As the main source of livelihood in Buol District, the land-based sector requires vast areas for economic development, and the demand for land for production of various commodities continues to grow. The result is conversion of land use and cover for agricultural commodities. These changes affect the ability of the landscape to store carbon stock, which is one of the main indicators of environmental services provided by the landscape.

In many cases, trade-offs between land provisions for developing land-based sectors and improving the ability of the landscape to store carbon stock is unavoidable. To address this issue, the local government in partnership with the relevant stakeholders in the district, needs to formulate scenarios of land use planning towards low-emission development.

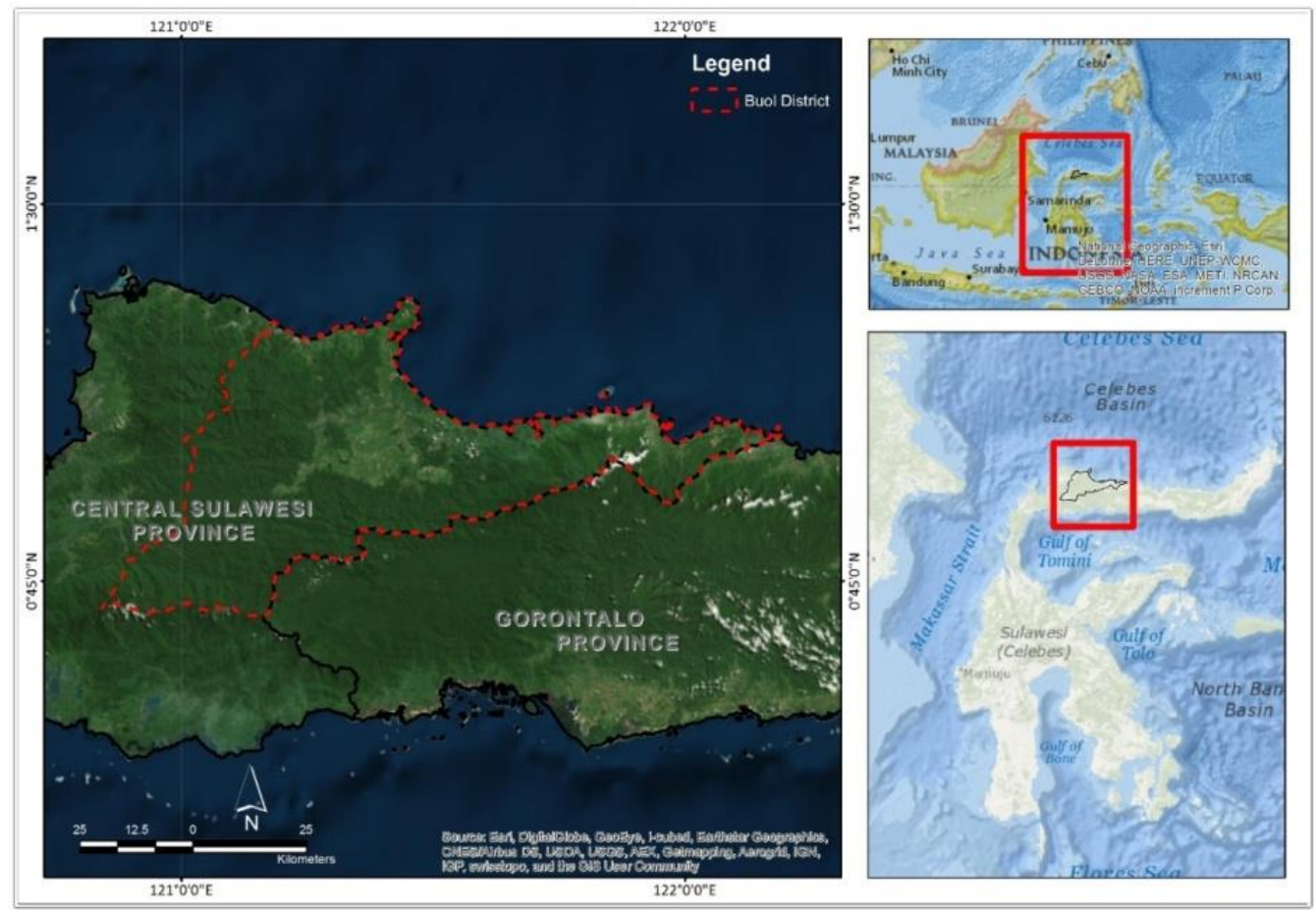

Figure 1. Location of Buol District, Central Sulawesi 


\subsection{Objectives}

The formulation of land use planning scenarios towards low-emission development goals requires valid data and information related to land use/cover changes dynamics and how this affects the landscape carbon emission in the district. To support the local government of Buol District with robust data and information, this study involved the:

1. Analysis of land use/cover changes dynamic during 1996-2014,

2. Measurement carbon stock at plot level, and

3. Estimation of carbon emission at landscape level.

This study also simulated the projection of carbon emission for the next 25 years based on a "business-as-usual" scenario, which may be taken as consideration in formulating district's land use planning scenarios towards low emission development in Buol District.

\section{Data and Methods}

The study of dynamics of land use/cover change and carbon emission was conducted in Buol District, Central Sulawesi. It applied the Analysis of Land-Use/cover Changes and Trajectories (ALUCT) Framework (Dewi and Ekadinata 2013) using a five time-series (1996, 2000, 2005, 2009 and 2014) dataset. The Landsat images were the input data used to identify land use/cover changes and its trajectories in Buol District during 1996-2014. The study also applied the Rapid Carbon Stock Appraisal (RaCSA) tool (Hairiah et al 2011) to obtain carbon stock data for all types of land use/cover in Buol District. Finally, both land use/cover changes data and carbon stock data were used as activity data and emission factors respectively, to estimate carbon emission produced by the district in the last two decades.

\subsection{Data}

\subsubsection{Ground-truth Data}

Ground-truth data is a set of sample points of land use/cover types directly taken in the field (ground) using global positioning system (GPS). Ground-truth data captured some information, including location/point coordinates, description of its location, type of land use/cover, accuracy of the sample point and photographs. This data is very important due to it defined land use/cover types that would be considered as land use systems for conducting object-based image analysis and measuring carbon stock in plot level. Furthermore, it could also be used to determine the accuracy of the overall process.

\subsubsection{Satellite Imageries}

This study used a five time-series dataset (1996, 2000, 2005, 2009 and 2014) of Landsat imageries with spatial resolution of 30m (Appendix 1). Before this dataset was ready to be used as input of image classification, its raw dataset had to go through image pre-processing to correct its radiometric and geometric errors caused by interference from the atmosphere. Once the dataset was ready, image classification using object-based image analysis (OBIA) was conducted to classify corrected Landsat imageries in order to produce a five time-series land use/cover data for Buol District. Further, the data was combined resulting in land use/cover changes and trajectories, which would be used as activity 
data of land management and practices to estimate the level of carbon emissions in Buol District in 1996-2014.

\subsubsection{Carbon Stock Data}

Carbon stock ( $\mathrm{C}$ stock) is the quantity of carbon stored in the landscape as aboveground and belowground living or dead plant biomass and soil. The ability of landscape to restore its $\mathrm{C}$ stock becomes an important variable in climate change issues. As the carbon stock stays on the ground, it has the potential to reduce the concentration of greenhouse gas emissions in the atmosphere. The amount of $\mathrm{C}$ stock (ton $\mathrm{C} / \mathrm{Ha}$ ) differs from landscape to landscape depending on plant diversity and density, soil type and land management (Hairiah et al 2011). C stock in a landscape may be higher, when its landscape has fertile soil and contains a high diversity and density of plants, as well as applies sustainable land management practices. Thus, how people managing their landscape to maintain biodiversity and to reduce climate-change vulnerability determines the amount of carbon stock.

\subsection{Methods}

\subsubsection{Analysis of Land Use/Cover Changes and Trajectories}

The general framework for identifying land use/cover changes and trajectories in Buol District is Analysis of Land-Use/cover Changes and Trajectories (ALUCT) (Dewi and Ekadinata 2013), which consists of five main stages as described below.

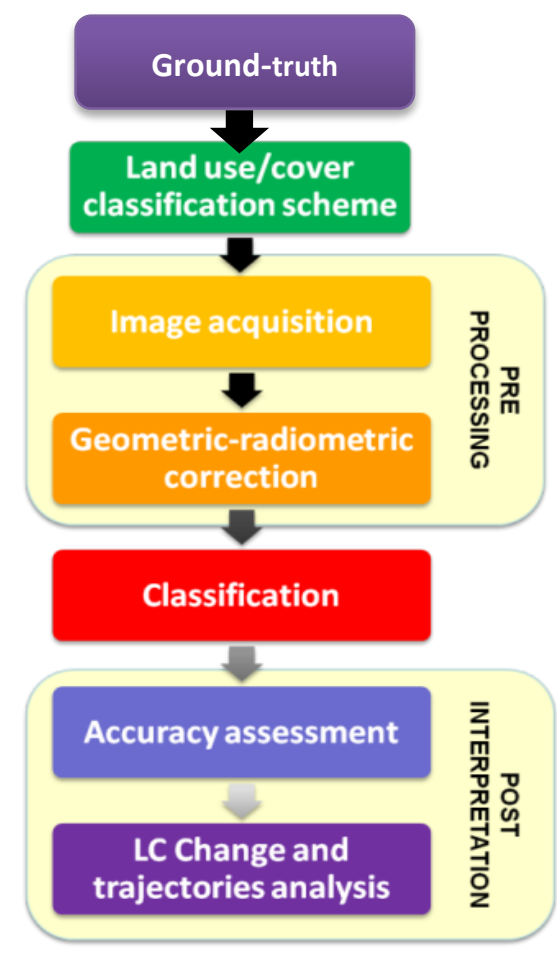

1. Ground-truth, collecting sample points of land use/cover using GPS, includes its descriptions and photos, as the basis for defining land use/cover classification scheme and conducting image classification

2. Clarification of the questions, leading to the level of detail needed in the legend of land cover types and the resolution of images needed to do so

3. Image acquisition and pre-processing: Selecting the resolution, spectral properties and source of the images, selecting an image date relevant to the study and of sufficient quality (low cloud cover)

4. Image classification based on ground-truth sample points and/or pre-established spatial patterns

5. Post interpretation analysis focused on the research questions of interest, usually linking 'land use' and system life cycles to the land cover types that can be recognized

Figure 2. Analysis of Land Use/Cover Change and Trajectories (ALUCT) framework (Dewi and Ekadinata 2013)

\section{Ground-truth}

Ground-truth was conducted in April 2014 in Buol District using rapid random sampling technique (Figure 3). The aim was to collect information of land use/cover types that exist in the 
district, including sample points coordinate using GPS, description of its location, type of land use/cover, accuracy of the sample point and photographs. The total number of ground-truth points collected was 306 points, including 107 location points and 199 land use/cover points. Ground-truth data is used as the basis for defining land use/cover classification schemes and conducting image classification, as well as reference locations for measuring carbon stock at plot level. The ground-truth data are also eligible as reference points for accuracy assessment of land use/cover.

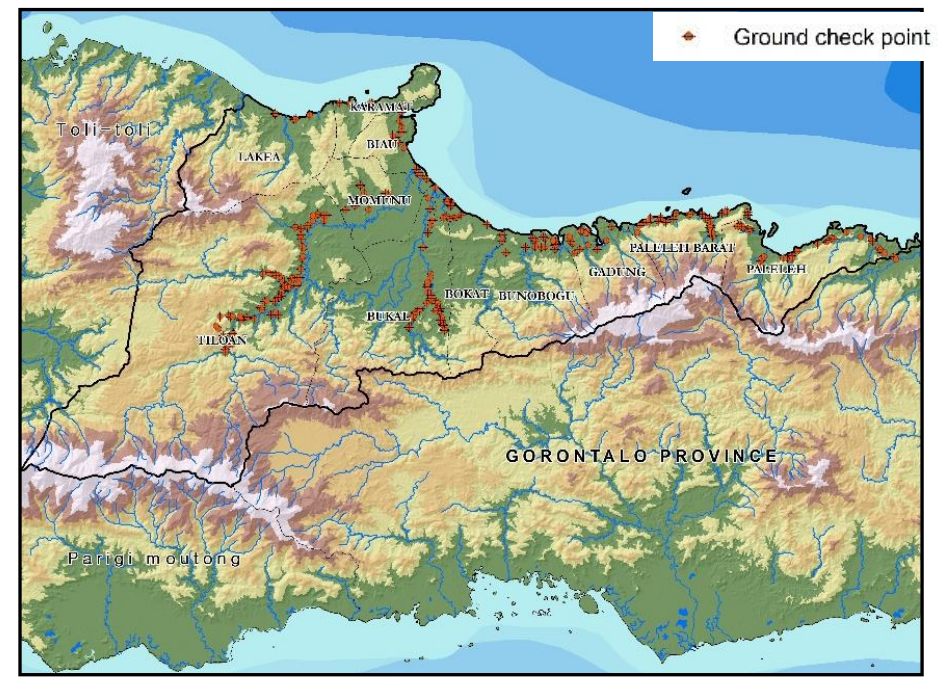

Figure 3. Distribution of ground-truth points

\section{Defining the land use/cover classification scheme}

Defining the land use/cover classification scheme requires initial information of land use/cover types in the study area, which may be obtained from sample points of land use/cover collected during the ground-truth activity, by holding discussions with local stakeholders, and through other related references/publication materials. Furthermore, defining the land use/cover classification scheme also requires knowledge of spatial and spectral properties of satellite images used. Both information and knowledge will determine the design of hierarchal level of land use/cover that will be applied in image classification in this study.

\section{Image pre-processing}

Image pre-processing is required to correct errors that occur on satellite images caused by disturbance from the atmosphere and topographical conditions. Image pre-processing consists of two main activities: radiometric and geometric corrections. To correct radiometric errors that occurs in Landsat images, this study used the Atmospheric and Topographic Correction for Satellite Imagery (ATCOR), a method used to reduce atmospheric and illumination effects on remotely sensed data to retrieve physical parameters of the earth's surface such as atmospheric conditions (emissivity, temperature), thermal and atmospheric radiance and transmittance functions in order to simulate the simplified properties of a 3D atmosphere ${ }^{1}$. Furthermore, geometric corrections were applied to some Landsat images which were identified to have geometric errors. On correcting geometric errors, this study used official base maps published by the Geospatial Information Agency (BIG). Additionally, for Landsat 7 Enhanced Thematic

\footnotetext{
${ }^{1}$ Source: http://www.satimagingcorp.com/svc/atcor.html
} 
Mapper Plus (ETM+) images that were released after May 2003, the images should be processed using SLC-OFF Gap Filling to correct errors caused by scan-line corrector (SLC) of Landsat 7 ETM+ failed on 31 May 2003.

\section{Image classification}

Image classification is a process that interprets spectral information from satellite images into land use/cover types. Hierarchal object-based classification (HOBC) is one of the many approaches that can be used to classify satellite images by considering ground-truth sample points and/or pre-established spatial patterns, as well as hierarchal classification schemes in the earlier stages. HOBC starts with the segmentation process to group similar spectral and spatial characteristics in the images into image objects (Figure 4). The segmentation process can be done in several phases to obtain the quality of land use/cover detail at different levels. Each level land use/cover type is interpreted using spectral and spatial rules. Details and complexity of land use/cover types increase at each level, therefore, each level applies a different set of rules. The outputs of these phases are called multi-resolution image segments, which work as a basis for the classification process done by the remote sensing application. This classification process may need several iterations until the classified images can describe the land use/cover types on the field.

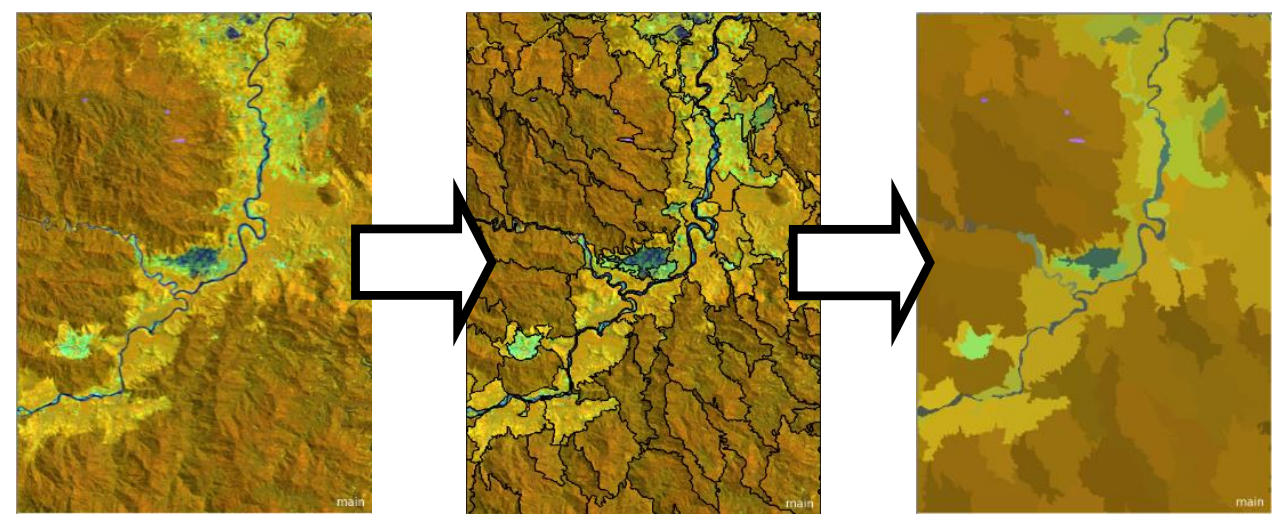

Figure 4. Segmentation process

\section{Post interpretation analysis}

Post interpretation analysis includes two main processes: accuracy assessment and land use/cover change and trajectories analysis. The accuracy assessment is required to assess the quality of land use/cover data produced in image classification by comparing the sample points of land use/cover types to corresponding pixels of the land use/cover data. Furthermore, the analysis of land use/cover change and trajectories aims to obtain advanced information on the changes of land use/cover area within a certain period, including the land use/cover transitions that are affecting the total area of land use/cover at the end of its period.

\section{$\underline{\text { Accuracy Assessment }}$}

The accuracy assessment consists of four types: user accuracy, producer accuracy, overall accuracy and Kappa coefficient (Congalton and Green 2009). The producer's accuracy was arrived at by dividing the number of correct pixels for a class by the actual number of reference pixels for that class, while the user's accuracy was arrived at by dividing the number of correct pixels for a class by the total pixels assigned to that class. The overall accuracy was produced by dividing the number of correct pixels for all classes by the total number of sample pixels for all 
classes. The Kappa coefficient expresses the proportionate reduction in error generated by a classification process compared with the error of a completely random classification, and it was calculated based upon the result of the error matrix and accuracy report.

\begin{tabular}{|c|c|c|c|c|}
\hline \multirow{5}{*}{$\begin{array}{l}\mathrm{i}=\text { Rows } \\
\text { (Classification) }\end{array}$} & $\begin{array}{r}j \\
1 \\
1\end{array}$ & $\begin{array}{l}\text { Columns } \\
\text { ference) } \\
\begin{array}{c|c}2 & \mathrm{k} \\
\mathrm{n}_{12} & \mathrm{n}_{1 \mathrm{k}}\end{array}\end{array}$ & \begin{tabular}{c|}
$\begin{array}{c}\text { Row } \\
\text { Total } \\
n_{1+}\end{array}$ \\
$n_{1+}$ \\
\end{tabular} & $\begin{array}{l}\text { Illustration of Error Matrix } \\
\text { and Mathematical } \\
\text { Expression for Accuracy } \\
\text { Assessment }\end{array}$ \\
\hline & $\mathrm{n}_{21}$ & $\mathrm{n}_{22}$ & $\mathrm{n}_{2+}$ & \\
\hline & $\mathrm{n}_{\mathrm{k} 1}$ & $\mathrm{n}_{\mathrm{k} 2}$ & $n_{k+}$ & $\sum_{j=1}$ \\
\hline & $\mathrm{n}_{+1}$ & $\mathrm{n}_{+2}$ & $\mathrm{n}$ & producer's accuracy $j=\frac{n_{j j}}{n_{+}}$ \\
\hline & $\hat{K}=-$ & $\sum_{i=1}$ & & $\begin{array}{l}\text { user's accuracy }_{i}=\frac{n_{i i}}{n_{i+}} \\
\text { overall accuracy }=\frac{\sum_{i=1}^{k} n_{i i}}{n} .\end{array}$ \\
\hline
\end{tabular}

Figure 5. Illustration of Error Matrix and Mathematical Expression for Accuracy Assessment (Congalton and Green 2009)

\section{Land Use/Cover Change and Trajectory Analysis}

Analysis of land use/cover change and trajectory may be done by overlaying the time series of land use/cover data, and extracting its tabular data to analyse the areas of change in land use/cover in the study area. The overlay process may also combine the administration boundary and land designation data to obtain information on where the changes are occurring. This study used five time series land use/cover (1996, 2000, 2005, 2009 and 2014), administration boundary, and land designation data of Buol District as illustrated in the figure below.

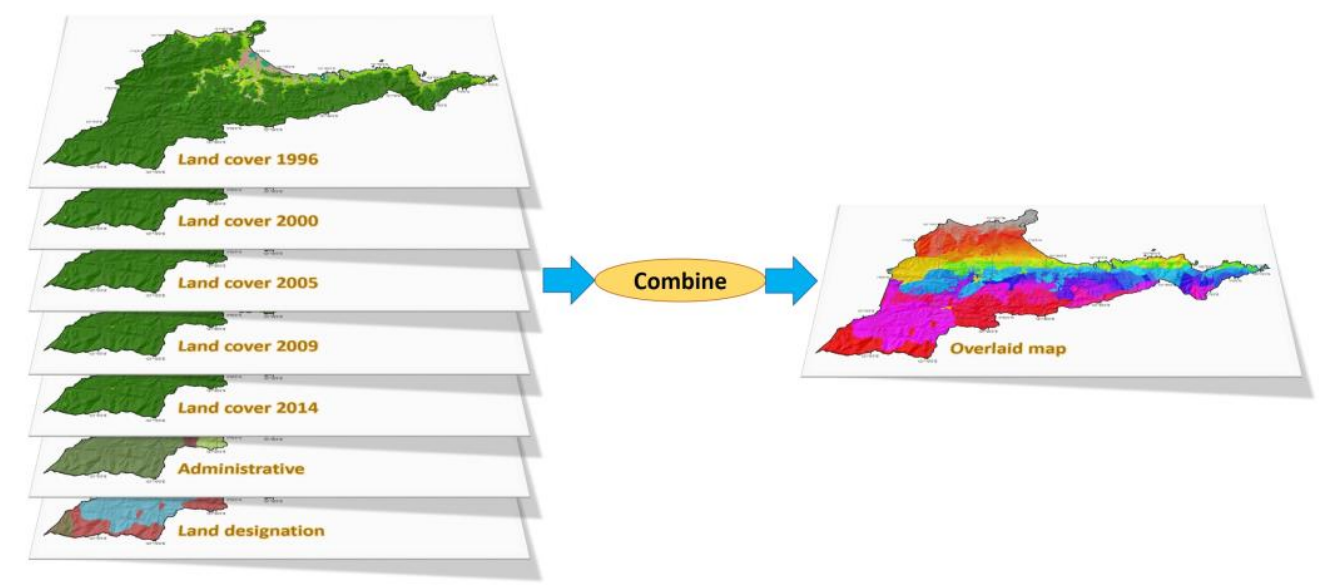

Figure 6. Illustration of overlaying process

\subsubsection{Plot-level Carbon Measurement}

Determining the $\mathrm{C}$ stock value starts by recognizing the life cycle of the system. Estimating the $\mathrm{C}$ stock can be achieved by taking representative samples that reflect the characteristics of the landscape 
(Hairiah et al 2011). The land use system (LUS) approach is a common approach to characterize landscape, which combines information on land cover, land use and management activities to come up with the life cycle of the system and to build representative samples of $\mathrm{C}$ stock in the landscape.

In this study, $\mathrm{C}$ stock data were taken from plot-level carbon measurement and other references that represents the $\mathrm{C}$ stock in 17 land use/cover types in Buol District. Nested sampling plots of variable sizes adjusted to the $\mathrm{C}$ pool sampled were used along with methods to estimate the tree size from stem diameter (and height) and destructive sampling of soil and necromass (Hairiah et al 2011).

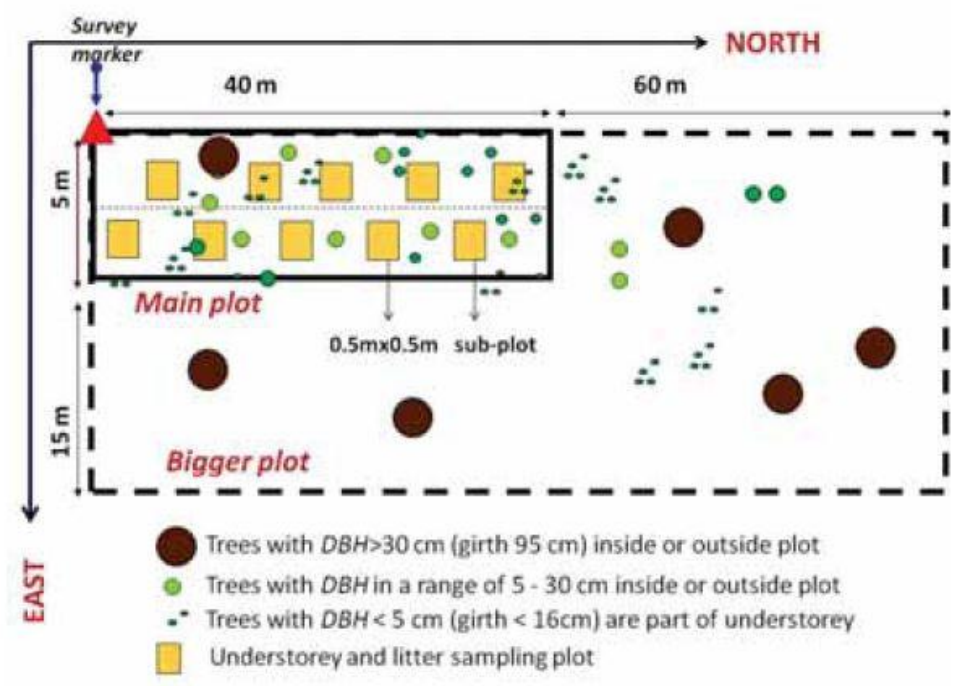

Figure 7. Diagram of nested plot for $\mathrm{C}$ stock measurement (Hairiah et al 2011)

\subsubsection{Landscape-level Carbon Emission Estimation}

Landscape-level carbon emission estimation requires two types of data: 1) area of land use/cover changes and trajectories (ha/year) as activity data; and 2) carbon stock change between land use/cover 1 to land use/cover 2 (ton C/ha) as an emission factor (Dewi et al 2011). Data about areas where changes of land use/cover have taken place is produced through land use/cover change analysis, while carbon stock change data is normally obtained from the difference between land use/cover 1 carbon stocks and land use/cover 2 that are measured in the field.

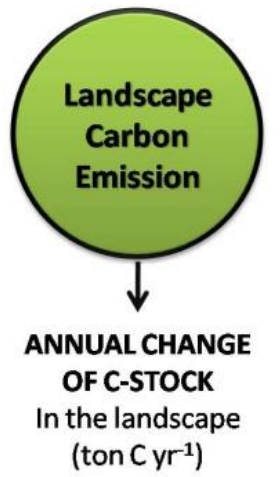

(ton $\mathrm{yr}^{-1}$ )

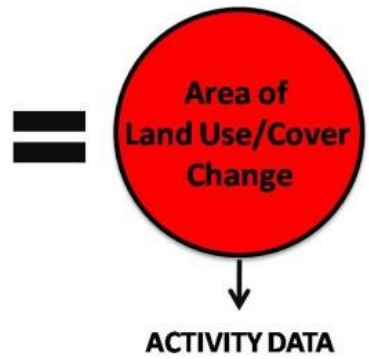

Area of changes between land use/cover 1 to land use/cover 2 $\left(\right.$ ha $\left.\mathrm{yr}^{-1}\right)$

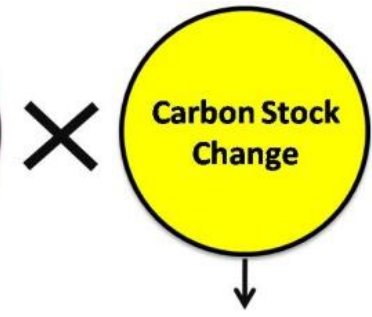

EMISSION FACTOR

Changes of carbon stock between land use/cover 1 to land use/cover 2 (ton C ha-1)

Figure 8. Landscape-level Carbon Emission Calculation (Dewi et al 2011) 


\section{Results}

\subsection{Land Use/Cover Classification}

Based on samples of land use/cover types and discussions with local stakeholders, the study defined 17 land use/cover types that exist in Buol District. To obtain land use/cover data that covers the 17 types defined earlier, the study designed a land use/cover classification scheme in which every type of land use/cover, both in each level and between different levels, must be distinguished from one another based on spatial and spectral characteristics of Landsat images used. Level 1 consists of the most general land use/cover types, which only distinguish vegetation and non-vegetation types. Level 2 consists of land use/cover types that are the detail types of Level 1, while Level 3 and subsequent levels are the detail types of its previous levels. In practice, this hierarchal scheme (Figure 9) was applied in the object-based image analysis that produced five time-series data of land use/cover types in Buol District (Figure 10).

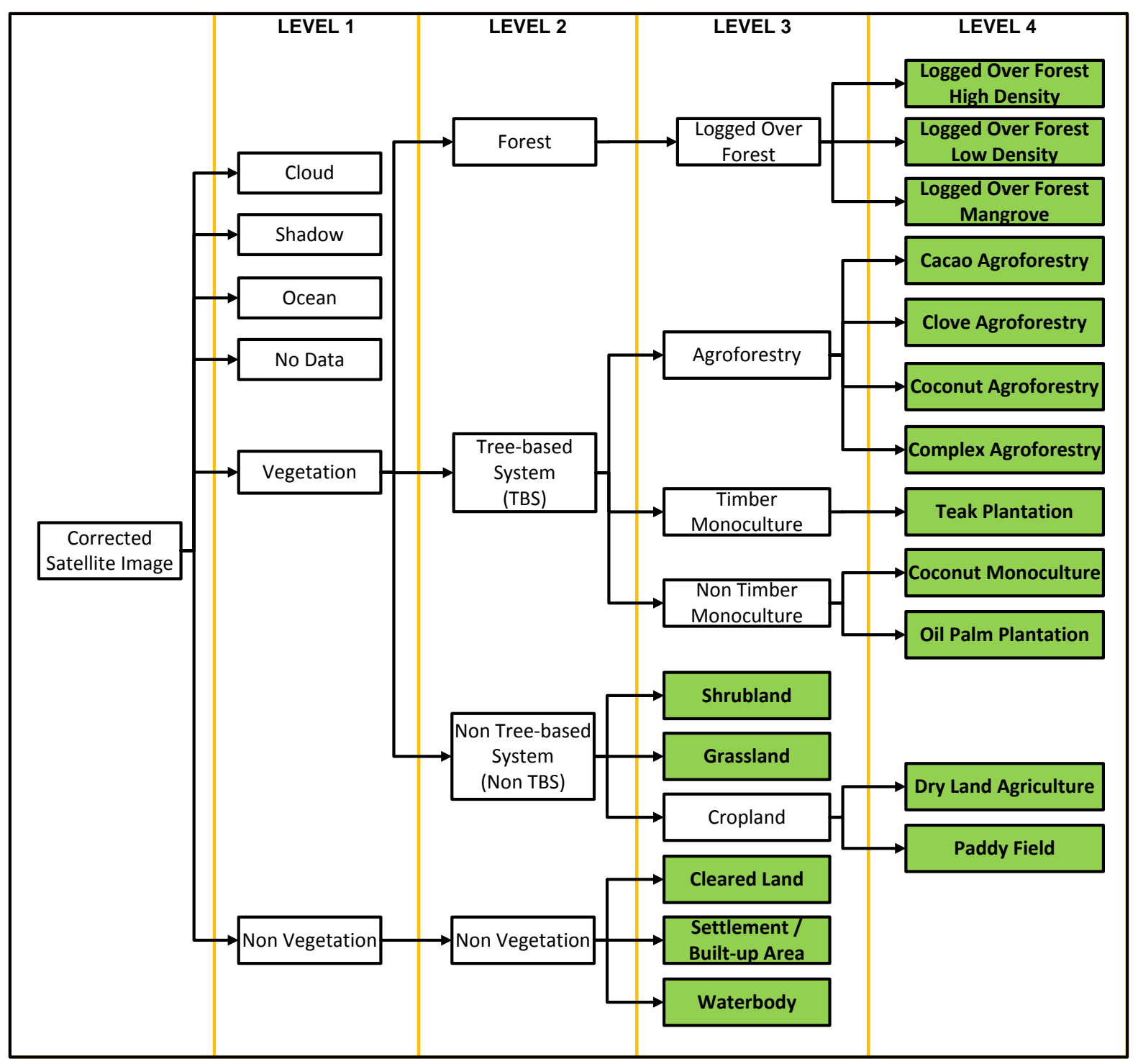

Figure 9. Hierarchal land use/cover classification scheme applied in Buol District 


\section{Box 1. Hierarchal land use/cover classification scheme}

- Level 1, six initial land use/cover types were defined: Non Vegetation, Vegetation, No Data, Ocean, Shadow, and Cloud. At the later stage, Cloud, Shadow, and Ocean were considered as No Data.

- Level 2, Non Vegetation remained Non Vegetation, whereas Vegetation was divided into three types: Forest, Tree-based System (TBS), and Non Tree-based System (Non TBS).

- Level 3, Non Vegetation (Level 2) was divided into three types: Cleared Land, Settlement, and Water body. These types became the three final types of Non Vegetation. The Non TBS was divided into Shrubland, Grassland and Cropland, while TBS was divided into Agroforestry, Timber Monoculture and Non Timber Monoculture. Due to the fact that most of the forest area in Buol has been logged or encroached upon, this level Forest only had one type, which is Logged Over Forest.

- Level 4, there were 12 defined land use/cover types; these are drawn from the five land use/cover types at Level 3. Dry Land Agriculture and Paddy Field were derived from Cropland; Coconut Monoculture and Oil Palm Plantation were derived from Non Timber Monoculture; and Teak Plantation was derived from Timber Monoculture. Furthermore, there were four types of Agroforestry (AF) in Buol: Cacao AF, Clove AF, Coconut AF and Complex AF; and three types of Logged Over Forest (LOF): LOF-High Density, LOF-Low Density, and LOF Mangrove.
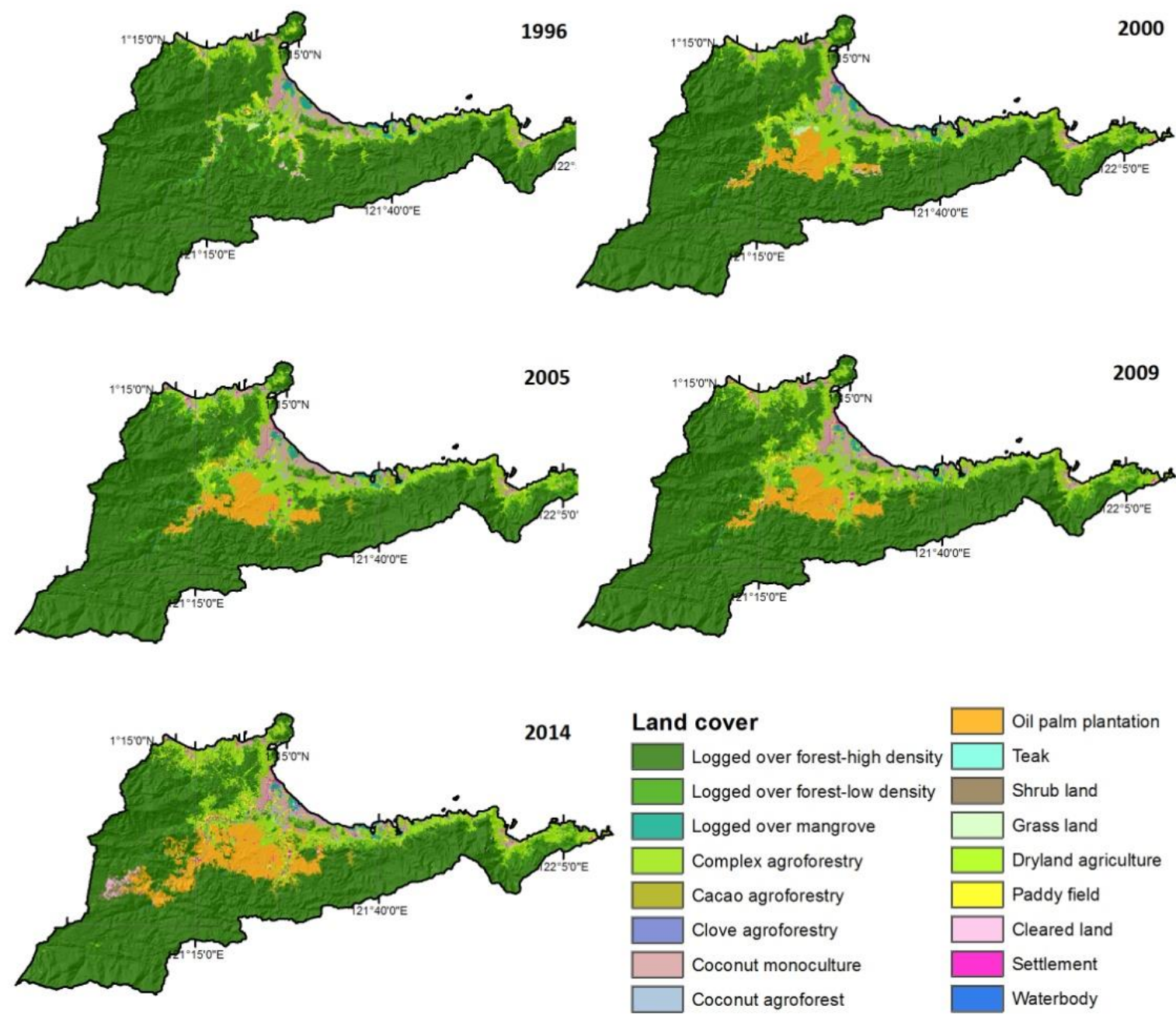

Figure 10. Figure 10. Time-series of land use/cover maps of Buol District 
To assess the quality of land use/cover maps produced, the study conducted an accuracy assessment based on the classified image 2014. The accuracy assessment used 199 sample points of land use/cover types taken from ground truth activity as the reference data. It resulted in an overall accuracy of $84.92 \%$ with kappa accuracy of $83.23 \%$ (see Appendix 1 for details). The result of this accuracy assessment indicated that the image classification and the map quality are robust enough as the threshold of a good quality map - both overall accuracy and kappa accuracy - were higher than $75 \%$.

The analysis found that Buol District with a total area of 385,708 hectares was dominated by LoggedOver Forest - High Density (LOF-HD), Logged Over Forest - Low Density (LOF-LD), and Complex Agroforestry (Table 1). These three were the largest land use/cover types in the district in 1996-2014. The LOF-HD and LOF-LD dominate the area with high elevation and steep slope, whereas Complex Agroforestry and other cultivation areas mostly occupied lower elevation and flatter areas in the northern part of Buol District.

Table 1. Land use/cover types in Buol District during 1996 - 2014

\begin{tabular}{rlrrrrr}
\hline ID & \multicolumn{1}{c}{ Land use/cover types } & \multicolumn{5}{c}{ Area (in hectares) } \\
& & 1996 & 2000 & 2005 & 2009 & 2014 \\
\hline $\mathbf{0}$ & No data & 262 & 262 & 262 & 262 & 262 \\
\hline $\mathbf{1}$ & Logged over forest - High density & 311,204 & 285,862 & 269,669 & 267,657 & 255,456 \\
\hline $\mathbf{2}$ & Logged over forest - Low density & 17,750 & 18,571 & 26,557 & 23,490 & 15,719 \\
\hline $\mathbf{3}$ & Logged over mangrove & 2,676 & 2,465 & 2,249 & 2,115 & 1,862 \\
\hline $\mathbf{4}$ & Complex agroforestry & 35,027 & 46,570 & 47,718 & 52,097 & 47,380 \\
\hline $\mathbf{5}$ & Cacao agroforestry & - & - & 2,079 & 1,392 & 1,288 \\
\hline $\mathbf{6}$ & Clove agroforestry & 250 & 256 & 281 & 281 & 281 \\
\hline $\mathbf{7}$ & Coconut monoculture & 8,156 & 8,419 & 8,911 & 8,412 & 8,412 \\
\hline $\mathbf{8}$ & Coconut agroforestry & 1,368 & 1,418 & 1,927 & 1,416 & 1,713 \\
\hline $\mathbf{9}$ & Oil palm plantation & - & 14,840 & 18,458 & 19,831 & 33,268 \\
\hline $\mathbf{1 0}$ & Teak plantation & - & - & 6 & 2 & 81 \\
\hline $\mathbf{1 1}$ & Shrub land & 993 & 59 & 440 & 227 & 5,686 \\
\hline $\mathbf{1 2}$ & Grass land & 676 & 669 & - & - & 69 \\
\hline $\mathbf{1 3}$ & Dry Land agriculture & 1 & 259 & 150 & 248 & 2,200 \\
\hline $\mathbf{1 4}$ & Paddy field & $\mathbf{3 8 5 , 7 0 8}$ & $\mathbf{3 8 5 , 7 0 8}$ & $\mathbf{3 8 5 , 7 0 8}$ & $\mathbf{3 8 5 , 7 0 8}$ & $\mathbf{3 8 5 , 7 0 8}$ \\
\hline $\mathbf{1 5}$ & Cleared land & 2,910 & 2,318 & 1,581 & 3,243 & 3,913 \\
\hline $\mathbf{1 6}$ & Settlement & 2,054 & 878 & 1,456 & 747 & 2,129 \\
\hline $\mathbf{1 7}$ & Water body & 362 & 931 & 1,822 & 2,075 & 3,173 \\
\hline & & & & & \\
\hline
\end{tabular}

2014 's overall accuracy $=84.92 \% \mid 2014$ 's Kappa accuracy $=83.23 \%$

\subsection{Land Use/Cover Changes and Trajectories}

Based on the analysis of land use/cover changes, four land use/cover types (i.e. LOF-HD, LOF-LD, Logged Over Mangrove, and Grassland) decreased during 1996-2014. LOF-HD and Logged Over Mangrove were decreasing constantly. LOF-HD decreased significantly by 55,748 $\mathrm{Ha}$ in the last two 
decades or 18\% of the initial area of LOF-HD in 1996, while Logged Over Mangrove decreased by $813 \mathrm{Ha}$ or $30 \%$ of its initial area. Slightly different from LOF-HD and Logged Over Mangrove, the areas of LOF-LD and Grassland fluctuated in size, but still, both land uses/covers decreased significantly.

Oil Palm Plantation and Complex Agroforestry increased considerably in 1996-2014. The development of Oil Palm Plantation was initiated in 2000, and had increased significantly since then. In 2014, the study found that approximately 33,268 Ha of Oil Palm Plantations had been established. Similar to Oil Palm Plantation, Complex Agroforestry also increased substantially. In total 12,354 Ha of new Complex Agroforestry was established in 1996-2014. The increasing area of Complex Agroforestry was also followed by other agroforestry types (i.e., cacao, coconut and clove agroforestry) and agriculture area (i.e. dry land agriculture and paddy fields). However, the rate of increase was not as high as that of Complex Agroforestry. An overview of land use/cover changes which occurred in Buol District are presented in Figure 11.

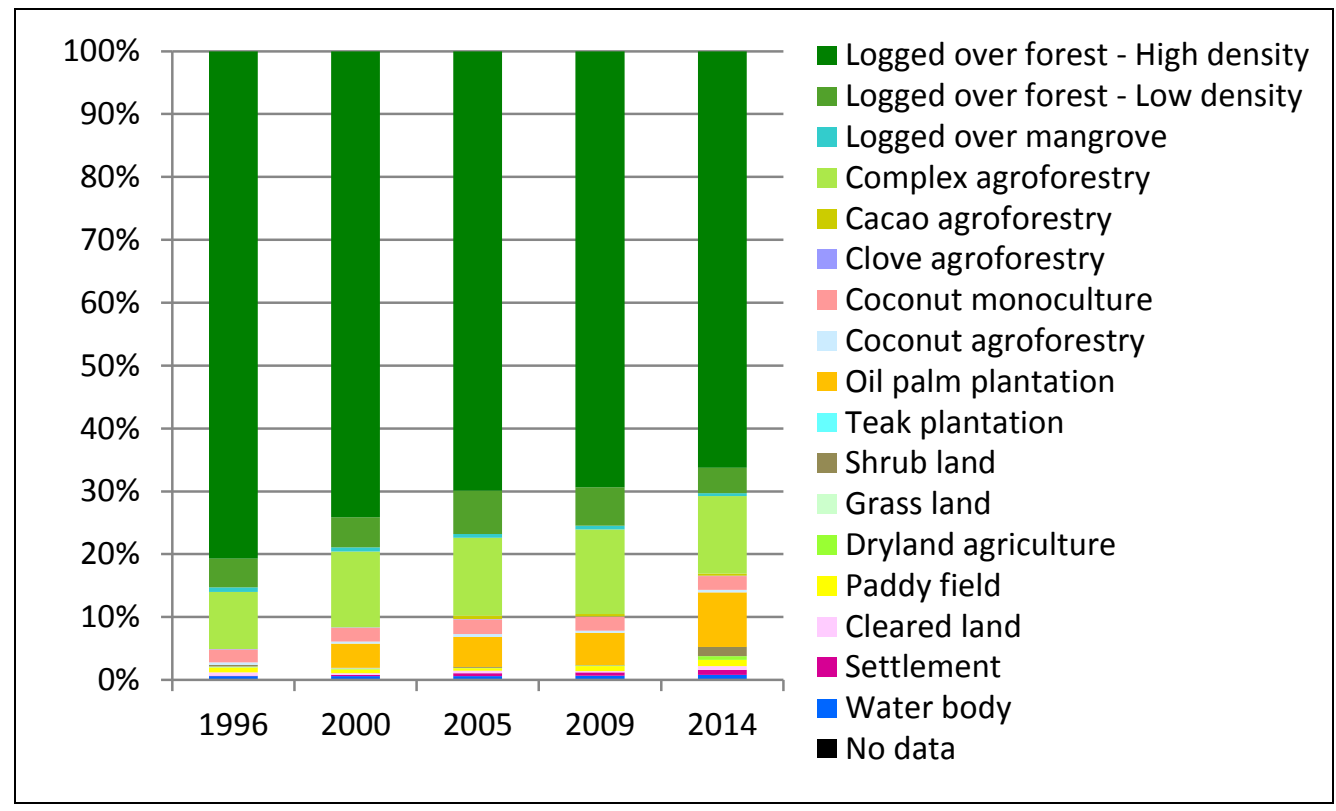

Figure 11. Proportion of land use/cover in Buol District during 1996 - 2014

To obtain more information on how the land use/cover changes occurred in Buol District, the study analyzed the land use/cover trajectories in order to examine the historical transitions from and/or to a land use/cover (Figure 12). Based on the result of the trajectories analysis, the study found that within the period 1996-2014, the area of Buol District was rapidly changing. In 1996-2000 the transformation was dominated by the conversion from Forest (LOF-HD and LOF-LD) to Complex Agroforestry and Oil Palm Plantation. This was the initial period of the Oil Palm establishment. During the next two periods (2000-2005 and 2005-2009), the trend of transition from Forest to Complex Agroforestry continued. Changes from Forest to Oil Palm Plantation was not the major one in Buol District. Within these two periods, Complex Agroforestry and Cleared Land were mostly transformed into Oil Palm Plantation. Forest was periodically converted into Oil Palm Plantation and Complex Agroforestry in the period of 2009-2014.

In summary, approximately $23 \%$ of the land use/cover of Buol District was changing during 19962014 dominated by the conversion from Forest to Complex Agroforestry (5\%), from Forest to Oil 
Palm Plantation (8\%), and from LOF-HD to LOF-LD (3\%). The data reveals that deforestation and forest degradation occurred in Buol by up to $13 \%$ and $3 \%$, respectively.
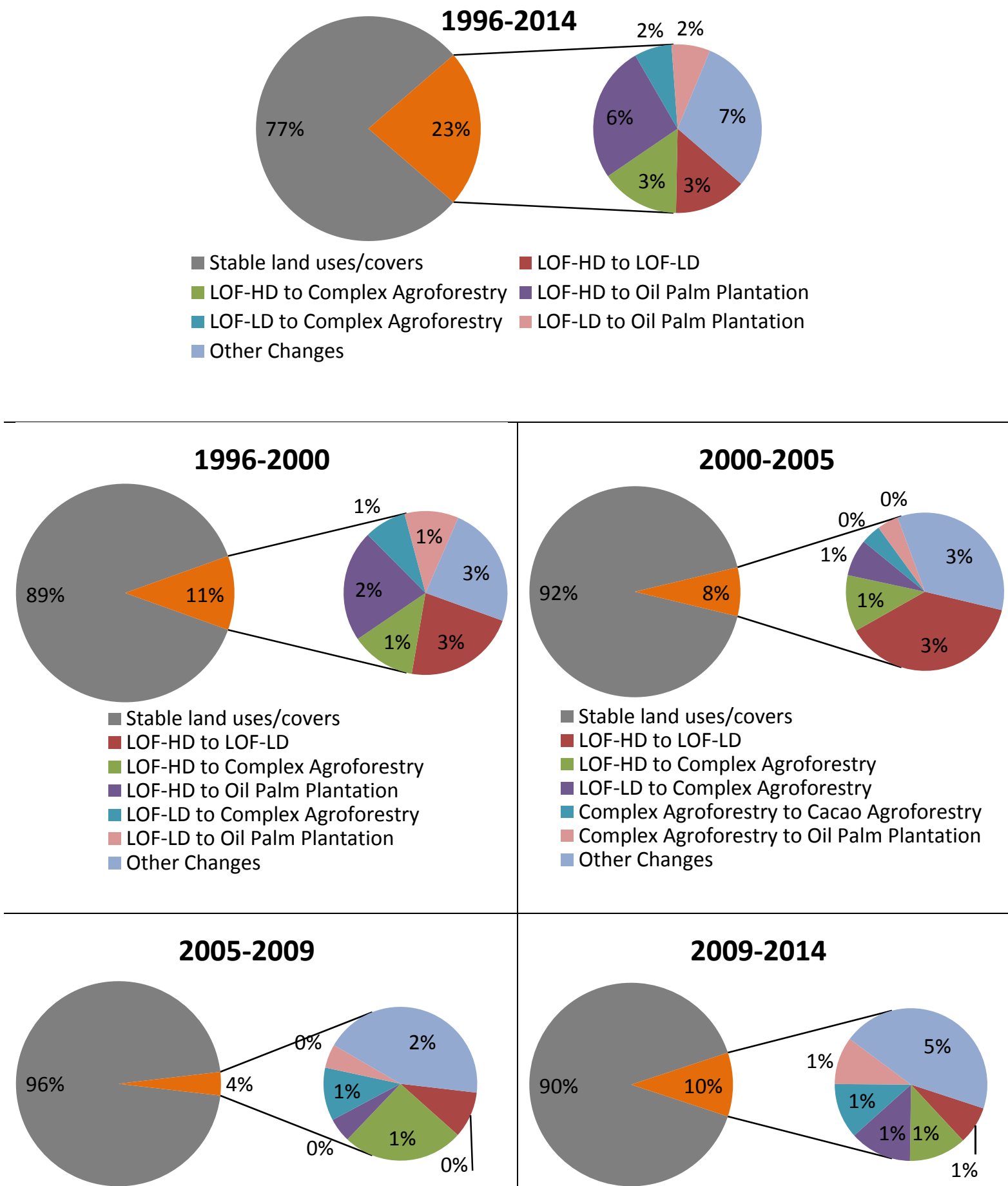

\section{9-2014}

Stable land uses/covers

- LOF-HD to LOF-LD

LOF-LD to Complex Agroforestry

- Complex Agroforestry to Oil Palm Plantation

- Complex Agroforestry to Paddy Field

Cleared Land to Complex Agroforestry

- Other Changes

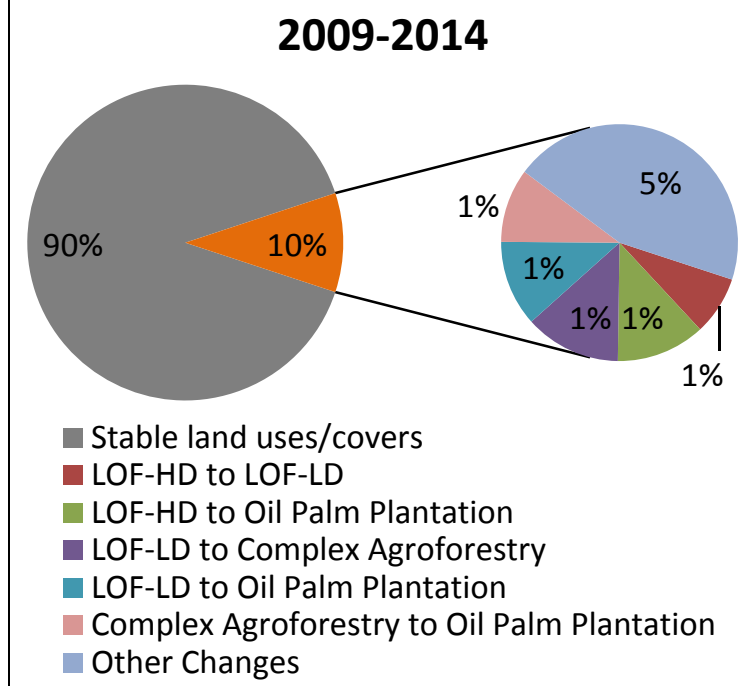

Figure 12. Major land use/cover trajectories in Buol District 


\subsection{Plot-level Carbon Stock Measurement}

The defined 17 final land use/cover types were considered for carbon stock data collection of Buol District. In this study, carbon stock data was collected by conducting plot-level carbon stock measurements for six land use/cover types in Buol District (as primary data) in October 2014 with a total of 23 plots, while the rests were taken from secondary carbon stock data from several locations in Indonesia collected during 2000-2014.

Based on the carbon stock data collected, the study found that Forest types (i.e. LOF-HD, LOF-LD and Logged Over Mangrove) and Agroforestry types store more carbon stock compared to Monoculture Plantations (i.e. teak, coconut, and oil palm). Furthermore, Agriculture types (i.e. dry land agriculture and paddy fields), shrubland and grassland store less carbon stock than Forest, Agroforestry and Monoculture plantations in the field. Table 2 provides a summary of the carbon stock data at different land covers in Buol.

Table 2. Land use/cover types and its carbon stock used in Buol District

\begin{tabular}{llrl} 
No & \multicolumn{1}{c}{ Land use cover } & $\begin{array}{r}\text { C stock } \\
\text { (ton C/Ha) }\end{array}$ & \multicolumn{1}{c}{ Sample Location } \\
\hline $\mathbf{1}$ & Logged over forest-high density & 181.4 & Central Sulawesi (Buol) \\
\hline $\mathbf{2}$ & Logged over forest-low density & 88.7 & Central Sulawesi (Buol) \\
\hline $\mathbf{3}$ & Logged over mangrove & 57.5 & Jambi (Tanjabar) \\
\hline $\mathbf{4}$ & Complex agroforestry & 80.9 & Central Sulawesi (Buol) \\
\hline $\mathbf{5}$ & Cacao agroforestry & 65.9 & Central Sulawesi (Buol) \\
\hline $\mathbf{6}$ & Clove agroforestry & 79.3 & Central Sulawesi (Buol) \\
\hline $\mathbf{7}$ & Coconut monoculture & 46.1 & South and Southeast Sulawesi \\
\hline $\mathbf{8}$ & Coconut agroforestry & 84.1 & Central Sulawesi (Buol) \\
\hline $\mathbf{9}$ & Oil palm plantation & 41.5 & Sumatra, Kalimantan, Sulawesi \\
\hline $\mathbf{1 0}$ & Teak plantation & 51.2 & East Kalimantan (Berau) \\
\hline $\mathbf{1 1}$ & Shrub land & 43.0 & Sumatra, Kalimantan, Sulawesi \\
\hline $\mathbf{1 2}$ & Grass land & 3.4 & Central Kalimantan \\
\hline $\mathbf{1 3}$ & Dry land agriculture & 1.0 & Sumatra \\
\hline $\mathbf{1 4}$ & Paddy field & 1.0 & Sumatra \\
\hline $\mathbf{1 5}$ & Cleared land & 0.0 & - \\
\hline $\mathbf{1 6}$ & Settlement & 0.0 & - \\
\hline $\mathbf{1 7}$ & Water body & 0.0 & - \\
\hline & & & \\
\hline
\end{tabular}

\subsection{Landscape Carbon Emission}

Landscape-level carbon emission is one of the parameters used to assess environmental services provided by a variety of land management in a landscape. Land use/cover changes reflects changes in land management, which in the end, results in change in carbon stock. Carbon emission from the landscape was calculated by using REDD Abacus $\mathbf{S P}^{2}$ software developed by the World Agroforestry

\footnotetext{
${ }^{2}$ http://worldagroforestry.org/regions/southeast_asia/resources/redd-abacus-sp
} 
Centre (ICRAF). Two basic pieces of information are required: (1) Land use/cover changes matrix in certain period providing information on land management and practices as the activity data and (2) Carbon stock data for each land use/cover as input to produce emission factors. Using this information, the software calculates the emission factors of each land use/cover change, and then multiplies its emission factors with the activity data (i.e. land use/cover changes matrix) to produce the Landscape Carbon Emission during a period of time.

In this study, carbon emission of Buol District was estimated by using data with 2009-2014 as the base period. The study found that during 2009-2014, the Net Carbon Emission in Buol District reached 1.8 million ton $\mathrm{CO}_{2}$-eq/year, as results of difference between total emission as of 1.9 million ton $\mathrm{CO}_{2}$-eq/year and total sequestration as of 101,499 ton $\mathrm{CO}_{2}$-eq/year. By applying forest delineation based on the forest land designation zones of Ministry of Forestry, the study showed that approximately $80 \%$ of the emissions occurred in Other Land Uses (APL) ${ }^{3}$, and up to $17 \%$ occurred in Production Forest zones (HP, HPT, and HPK) ${ }^{4}$ (Figure 13).
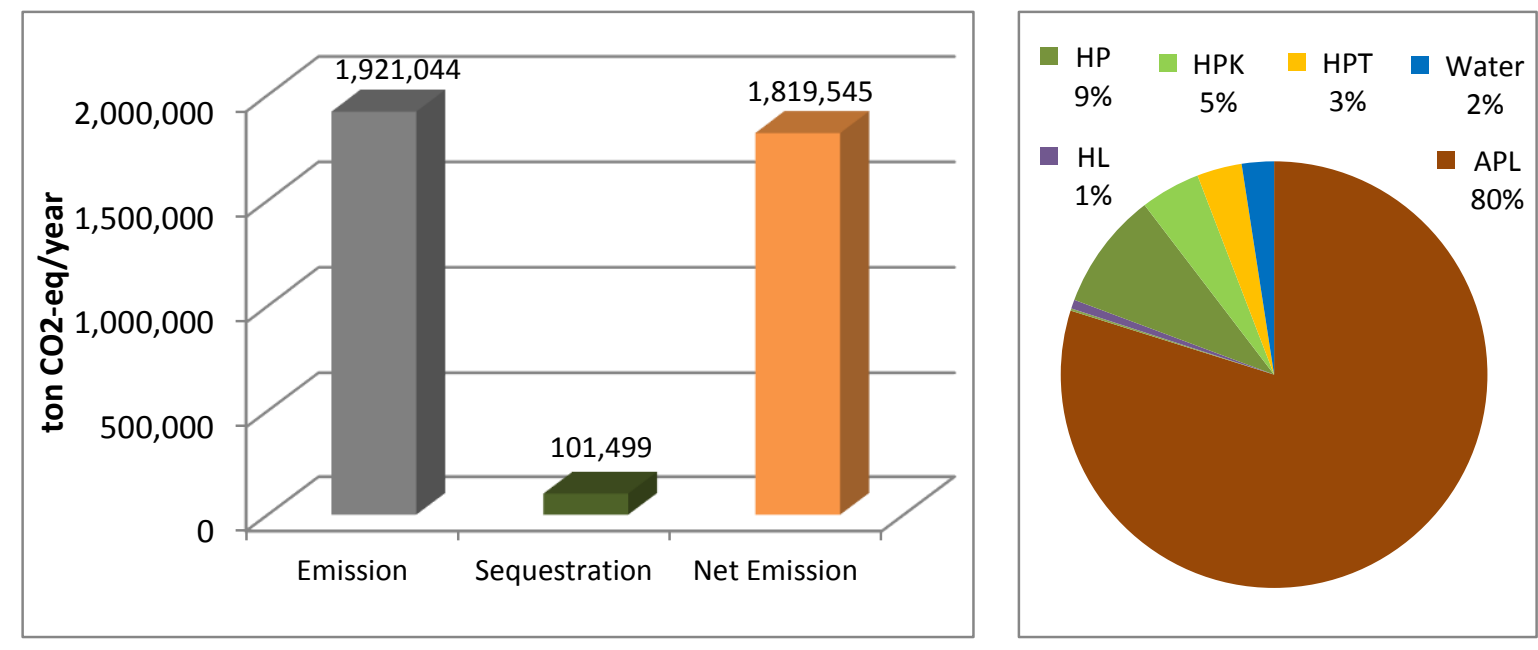

Figure 13. Annual carbon emission and the contribution of each land designation in Buol District (2009 - 2014)

To get advanced information on contribution of land management affecting carbon emission, the study analyzed 10 types of land use/cover transition that produced large carbon emission in the district (Figure 14). The conversion from LOF-HD, LOF-LD, and Complex Agroforestry to other land use/cover became the largest contributors of carbon emission in Buol District. The LOF-HD conversions to Oil Palm Plantation, Cleared Land, Shrub Land, and LOF-LD contributed 53\% of total net carbon emission, whereas the Complex Agroforestry conversions to Paddy Field, Oil Palm Plantation, Dryland Agriculture, and Shrubland contributed 19\% of the net emission. In addition to this, the LOF-LD conversion to Oil Palm Plantation also contributed a significant amount of carbon emissions by $8 \%$ of the net emission. Most of these carbon emission contributors were located in APL zones, except the LOF-LD conversion to Oil Palm Plantation that was occurred in HP zones.

\footnotetext{
${ }^{3}$ Other Land Uses/Areal Penggunaan Lain (APL)

${ }^{4}$ Types of Production Forest: Production Forest/Hutan Produksi Tetap (HP), Limited Production Forest/Hutan Produksi Terbatas (HPT), and Convertible Production Forest/Hutan Produksi Konversi (HPK)
} 


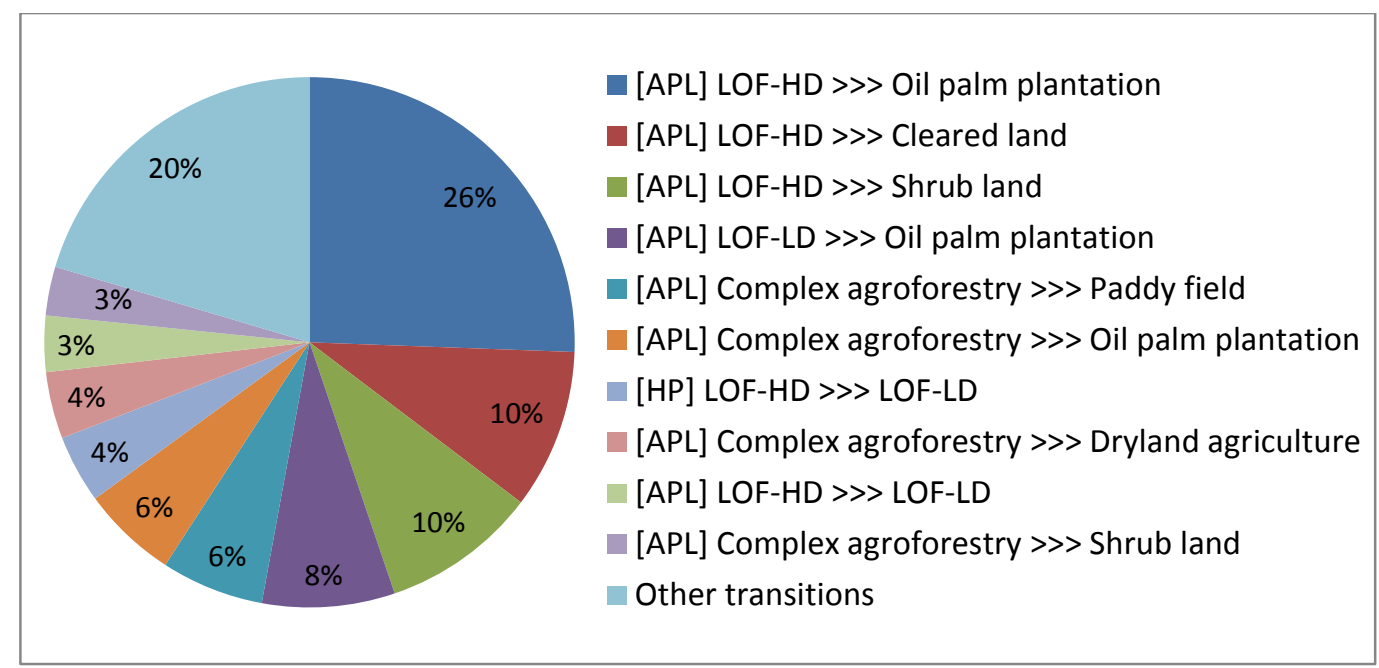

Figure 14. Contributions of land use/cover conversions to carbon emission in Buol District (2009-2014)

\section{Discussions}

During 1996-2014, Buol District has been experiencing significant land use/cover changes. About $23 \%$ of the total area has changed. The changes were dominated by the conversion from (1) Forest to Complex Agroforestry (5\%), (2) Forest to Oil Palm Plantation (8\%), and (3) LOF-HD to LOF-LD (3\%). In addition to these changes, around $2 \%$ of Buol District was also deforested into intermediate land use/cover (Shrub land and Cleared Land) by $1.4 \%$, Other Agroforestry $(0.3 \%)$, and Agriculture $(0.3 \%)$. As a result, both Complex Agroforestry and Oil Palm Plantation were the largest land use/cover types after LOF-HD in 2014. The study showed that Forest became the main origin of the extensive development of Oil Palm Plantation and Complex Agroforestry in the last two decades in Buol District.

These findings have been confirmed by the communities at three clusters of the World Agroforestry Centre's pilot projects (Upstream, Midstream and Coastal). The Focus Group Discussions (FGDs) in these clusters revealed that the development of Agroforestry and Oil Palm Plantation from Forest conversion would continue, and together with paddy fields, both land use/cover types will still dominate their clusters in the next 10 years (Tanika et al 2015). Communities in three clusters also described that these land use cover changes were driven by socio-economic motives, such as (1) population growth, (2) land productivity and profitability, (3) land provision for agriculture and plantation, and (4) income and livelihood driven.

Carbon emission as a result of land use/cover changes was analyzed for the period of 2009-2014. The analysis suggested that the transition from Forest to Oil Palm Plantation contributed to 35\% of net emission and changes from Forest to Complex Agroforestry contributed only 5\% of net emission in Buol District. The carbon emission emitted by the transition from Forest to Oil Palm Plantation was seven times larger than Complex Agroforestry even though the total area of conversion from Forest to Oil Palm Plantation was only 1.5 times larger than Complex Agroforestry. This significant difference in carbon emission from those two types of transitions was due to the ability of Complex Agroforestry to store carbon nearly two times larger than the one of Oil Palm Plantation. This ability will affect to emission factor of Complex Agroforestry development that is lower than emission factor of Oil Palm Plantation development. Overall, at the landscape level, deforestation and forest degradation activities 
contributed 77.6\% of total net emission in Buol District during 2009-2014. If the "business-as-usual" (BAU) scenario is applied for the next 25 years, then the net carbon emission produced by Buol District will increase by up to 6.5 million ton $\mathrm{CO}_{2}$-eq/year, or in total about 32.43 million ton $\mathrm{CO}_{2}$-eq during 2034-2039. Figure 15 shows the projection of carbon emission in the next 25 years as result of the BAU scenario.

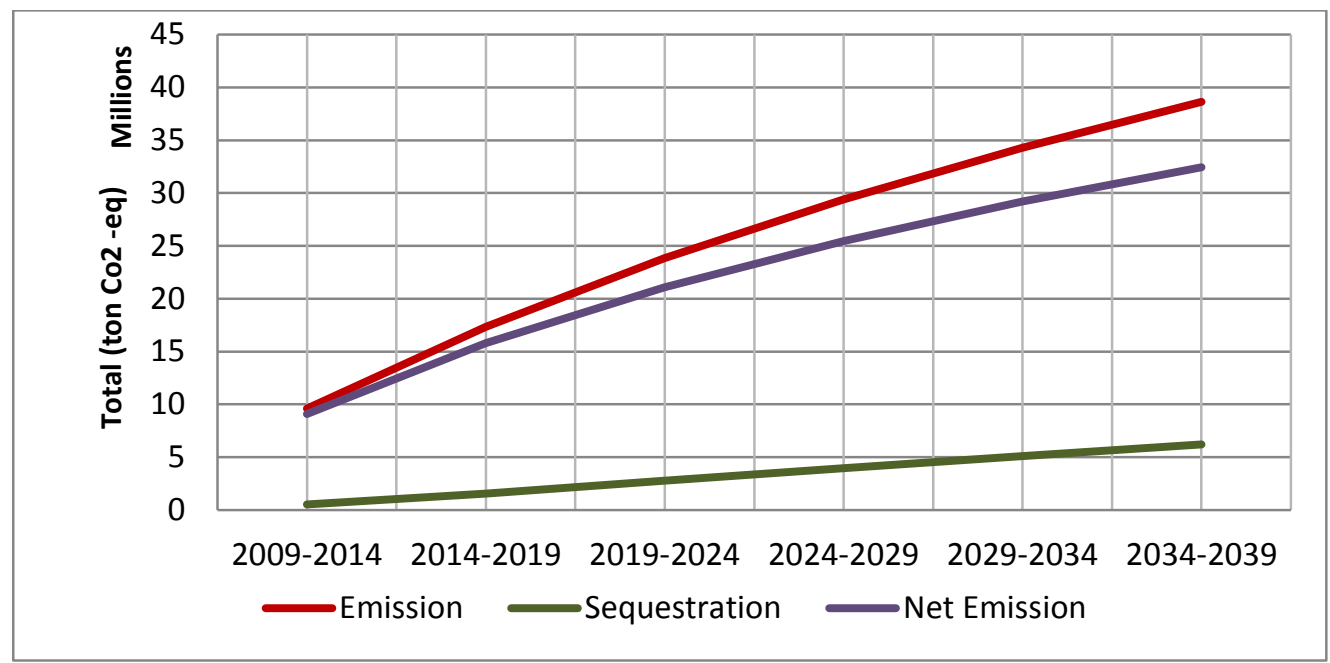

Figure 15. The projection of carbon emission for the next 25 years using the "business-as-usual" scenario

\section{Conclusion and Recommendation}

The projection of carbon emissions for the next 25 years as a result of BAU land management and practices will provide important notice to the local government on the potential of the District to contribute to high carbon emissions resulting in climate change. Existing literature indicates that climate change leads to several environmental problems, such as floods and droughts, sea level rise, changes in seasonal periods (climate), and changes in the ecosystem. At the local level, these environmental problems lead to uncertainty on planting periods, soil erosion, landslides, and less fresh water, all of which will have a negative impact on the livelihoods of people living in Buol District and the surrounding area. As a trade-off, extensive land development may increase the economic value of its land along with the land use profitability that is usually higher than unmanaged land.

Considering the trade-off between reducing emission and maintaining economic growth in land-based sectors, land use planning for low emission development strategy becomes one of the options as it balances development activities that emit carbon with activities that sequester carbon, while maintaining economic growth of the district. Under the land use planning for low emission development strategy, there are four major activities that may be relevant with the current situation of land-based development in Buol District:

1. Maximize the utilization of intermediate land uses/covers (shrub land and cleared land) for productive land-based development that may benefit both livelihood and carbon sequestration,

2. Promoting an agroforestry system that combine trees and crops that may increase carbon stock in the field as well as benefit livelihood of local communities, 
3. Avoid forest conversion to extensive land-based development, such as monoculture oil palm plantation, to reduce emission from deforestation and forest degradation, and

4. Conserve high carbon stock (HCS) and high conservation value (HCV) areas that are providing environmental services for people and the ecosystem.

Finally, to ensure commitment of stakeholders in implementing this strategy, the local government should integrate the strategy into the District Development Plan and District Spatial Plan, so that the implementation can also be monitored and evaluated as part of the district agenda. 


\section{References}

Congalton RG and Green K. 2009. Assessing the Accuracy of Remotely Sensed Data: Principles and Practices (Second Edition). Florida, United States of America. Taylor \& Francis Group, LLC. ISBN-13: 978-14200-5512-2.

Dewi S, Ekadinata A, Galudra G, Agung P and Johana F. 2011. LUWES: Land use planning forLow Emission Development Strategy. Bogor, Indonesia. World Agroforestry Centre (ICRAF) Southeast Asia Regional Program. 47 p.

Dewi S and Ekadinata A. 2013. Analysis of land-use and -cover trajectory (ALUCT). In: van Noordwijk M, Lusiana B, Leimona B, Dewi S and Wulandari D (eds). Negotiation-support toolkit for learning landscapes. Bogor, Indonesia. World Agroforestry Centre (ICRAF) Southeast Asia Regional Program. P. 110-117. http://regions/southeast_asia/publicationsdo=view_pub_detail\&pub_no=BC0365-13-10.

Hairiah K, Dewi S, Agus F, Velarde S, Ekadinata A, Rahayu S and van Noordwijk M. 2011. Measuring Carbon Stocks Across Land Use Systems: A Manual. Bogor, Indonesia. World Agroforestry Centre (ICRAF) Southeast Asia Regional Program. 154 pages.

Statistics of Buol Regency. 2015. Buol Regency in Figures 2015. Buol, Indonesia. Statistics of Buol Regency, 183 pages. ISSN: 979.480 .634 .12

Tanika L, Amaruzaman S, Lusiana B, Dwiyanti E, Rahayu S, Wijaya C. 2015. Cluster Profile Smart Tree-invest sites in Buol regency, Indonesia. Bogor, Indonesia. World Agroforestry Centre (ICRAF) - Southeast Asia Regional Program. 24p 


\section{Appendices}

Appendix 1. List of Landsat Imageries

\begin{tabular}{|c|c|c|c|c|c|}
\hline Datasets & Path/Row & Data & Acquisition Date & Spatial Resolution & Source \\
\hline \multirow[t]{2}{*}{1996} & $113 / 059$ & Landsat 4 TM & January 10, 1991 & \multirow[t]{2}{*}{30 metres } & \multirow[t]{2}{*}{ USGS-NASA } \\
\hline & $114 / 059$ & Landsat 5 TM & August 2, 1996 & & \\
\hline \multirow[t]{2}{*}{2000} & $113 / 059$ & Landsat 7 ETM+ & January 17, 2000 & \multirow[t]{2}{*}{30 metres } & \multirow[t]{2}{*}{ USGS-NASA } \\
\hline & $114 / 059$ & Landsat 5 TM & July 12,2000 & & \\
\hline \multirow[t]{3}{*}{2005} & $113 / 059$ & Landsat 7 ETM+ & May 21, 2004 & \multirow[t]{3}{*}{30 metres } & \multirow[t]{3}{*}{ USGS-NASA } \\
\hline & $114 / 059$ & Landsat 7 ETM+ & September 20, 2005 & & \\
\hline & & & October 22, 2005 & & \\
\hline \multirow[t]{3}{*}{2009} & $113 / 059$ & Landsat 7 ETM+ & October 13, 2010 & \multirow[t]{3}{*}{30 metres } & \multirow[t]{3}{*}{ USGS-NASA } \\
\hline & $114 / 059$ & Landsat 7 ETM+ & January 18, 2009 & & \\
\hline & & & May 10, 2009 & & \\
\hline \multirow[t]{3}{*}{2014} & $113 / 059$ & LCDM 8 OLI & March 20, 2013 & \multirow[t]{3}{*}{30 metres } & \multirow[t]{3}{*}{ USGS-NASA } \\
\hline & $114 / 059$ & LCDM 8 OLI & January 14, 2014 & & \\
\hline & & & February 9, 2014 & & \\
\hline
\end{tabular}

Appendix 2. Summary of accuracy assessment of land use/cover 2014

\begin{tabular}{|clccccc}
\hline No. & Land use/cover & $\begin{array}{c}\text { Reference } \\
\text { totals }\end{array}$ & $\begin{array}{c}\text { Classified } \\
\text { totals }\end{array}$ & $\begin{array}{c}\text { Number } \\
\text { correct }\end{array}$ & $\begin{array}{c}\text { Producer } \\
\text { accuracy }\end{array}$ & $\begin{array}{c}\text { User } \\
\text { accuracy }\end{array}$ \\
\hline $\mathbf{1}$ & Logged over forest - High density & 14 & 14 & 14 & $100 \%$ & $88 \%$ \\
\hline $\mathbf{2}$ & Logged over forest - Low density & 3 & 3 & 3 & $100 \%$ & $75 \%$ \\
\hline $\mathbf{3}$ & Logged over mangrove & 4 & 4 & 4 & $100 \%$ & $100 \%$ \\
\hline $\mathbf{4}$ & Complex agroforestry & 35 & 35 & 30 & $86 \%$ & $83 \%$ \\
\hline $\mathbf{5}$ & Cacao agroforestry & 15 & 15 & 12 & $80 \%$ & $100 \%$ \\
\hline $\mathbf{6}$ & Clove agroforestry & 7 & 7 & 5 & $71 \%$ & $100 \%$ \\
\hline $\mathbf{7}$ & Coconut monoculture & 6 & 6 & 6 & $100 \%$ & $75 \%$ \\
\hline $\mathbf{8}$ & Coconut agroforestry & 6 & 6 & 4 & $67 \%$ & $100 \%$ \\
\hline $\mathbf{9}$ & Oil palm plantation & 18 & 18 & 17 & $94 \%$ & $68 \%$ \\
\hline $\mathbf{1 0}$ & Teak plantation & 4 & 4 & 2 & $50 \%$ & $100 \%$ \\
\hline $\mathbf{1 1}$ & Shrub land & 11 & 11 & 8 & $73 \%$ & $62 \%$ \\
\hline $\mathbf{1 2}$ & Grass land & - & - & - & - & - \\
\hline $\mathbf{1 3}$ & Dry land agriculture & 15 & 15 & 14 & $93 \%$ & $93 \%$ \\
\hline $\mathbf{1 4}$ & Paddy field & 13 & 13 & 10 & $77 \%$ & $91 \%$ \\
\hline $\mathbf{1 5}$ & Cleared land & 1 & 1 & 0 & $0 \%$ & $0 \%$ \\
\hline $\mathbf{1 6}$ & Settlement & 35 & 35 & 29 & $83 \%$ & $94 \%$ \\
\hline $\mathbf{1 7}$ & Water body & 12 & 12 & 11 & $92 \%$ & $92 \%$ \\
\hline & & 199 & 199 & 169 & & \\
\hline $\mathbf{2 1 4}$ & Total & & & & \\
\hline
\end{tabular}

2014's overall accuracy $=84.92 \%$

2014's Kappa accuracy $=83.23 \%$ 



\section{WORKING PAPERS WITH DOIS}

\section{5}

1. Agroforestry in the drylands of eastern Africa: a call to action

2. Biodiversity conservation through agroforestry: managing tree species diversity within a network of community-based, nongovernmental, governmental and research organizations in western Kenya.

3. Invasion of prosopis juliflora and local livelihoods: Case study from the Lake Baringo area of Kenya

4. Leadership for change in farmers organizations: Training report: Ridar Hotel, Kampala, 29th March to 2nd April 2005.

5. Domestication des espèces agroforestières au Sahel : situation actuelle et perspectives

6. Relevé des données de biodiversité ligneuse: Manuel du projet biodiversité des parcs agroforestiers au Sahel

7. Improved land management in the Lake Victoria Basin: TransVic Project's draft report.

8. Livelihood capital, strategies and outcomes in the Taita hills of Kenya

9. Les espèces ligneuses et leurs usages: Les préférences des paysans dans le Cercle de Ségou, au Mali

10. La biodiversité des espèces ligneuses: Diversité arborée et unités de gestion du terroir dans le Cercle de Ségou, au Mali

\section{6}

11. Bird diversity and land use on the slopes of Mt. Kilimanjaro and the adjacent plains, Tanzania

12. Water, women and local social organization in the Western Kenya Highlands

13. Highlights of ongoing research of the World Agroforestry Centre in Indonesia

14. Prospects of adoption of tree-based systems in a rural landscape and its likely impacts on carbon stocks and farmers' welfare: The FALLOW Model Application in Muara Sungkai, Lampung, Sumatra, in a 'Clean Development Mechanism' context

15. Equipping integrated natural resource managers for healthy Agroforestry landscapes.

17. Agro-biodiversity and CGIAR tree and forest science: approaches and examples from Sumatra.

18. Improving land management in eastern and southern Africa: A review of policies.

19. Farm and household economic study of Kecamatan Nanggung, Kabupaten Bogor, Indonesia: A socioeconomic base line study of Agroforestry innovations and livelihood enhancement.

20. Lessons from eastern Africa's unsustainable charcoal business.

21. Evolution of RELMA's approaches to land management: Lessons from two decades of research and development in eastern and southern Africa

22. Participatory watershed management: Lessons from RELMA's work with farmers in eastern Africa.

23. Strengthening farmers' organizations: The experience of RELMA and ULAMP.

24. Promoting rainwater harvesting in eastern and southern Africa.

25. The role of livestock in integrated land management.

26. Status of carbon sequestration projects in Africa: Potential benefits and challenges to scaling up.

27. Social and Environmental Trade-Offs in Tree Species Selection: A Methodology for Identifying Niche Incompatibilities in Agroforestry [Appears as AHI Working Paper no. 9]

28. Managing tradeoffs in agroforestry: From conflict to collaboration in natural resource management. [Appears as AHI Working Paper no. 10]

29. Essai d'analyse de la prise en compte des systemes agroforestiers pa les legislations forestieres au Sahel: Cas du Burkina Faso, du Mali, du Niger et du Senegal.

30. Etat de la recherche agroforestière au Rwanda etude bibliographique, période 1987-2003 
31. Science and technological innovations for improving soil fertility and management in Africa: A report for NEPAD's Science and Technology Forum.

32. Compensation and rewards for environmental services.

33. Latin American regional workshop report compensation.

34. Asia regional workshop on compensation ecosystem services.

35. Report of African regional workshop on compensation ecosystem services.

36. Exploring the inter-linkages among and between compensation and rewards for ecosystem services CRES and human well-being

37. Criteria and indicators for environmental service compensation and reward mechanisms: realistic, voluntary, conditional and pro-poor

38. The conditions for effective mechanisms of compensation and rewards for environmental services.

39. Organization and governance for fostering Pro-Poor Compensation for Environmental Services.

40. How important are different types of compensation and reward mechanisms shaping poverty and ecosystem services across Africa, Asia \& Latin America over the Next two decades?

41. Risk mitigation in contract farming: The case of poultry, cotton, woodfuel and cereals in East Africa.

42. The RELMA savings and credit experiences: Sowing the seed of sustainability

43. Yatich J., Policy and institutional context for NRM in Kenya: Challenges and opportunities for Landcare.

44. Nina-Nina Adoung Nasional di So! Field test of rapid land tenure assessment (RATA) in the Batang Toru Watershed, North Sumatera.

45. Is Hutan Tanaman Rakyat a new paradigm in community based tree planting in Indonesia?

46. Socio-Economic aspects of brackish water aquaculture (Tambak) production in Nanggroe Aceh Darrusalam.

47. Farmer livelihoods in the humid forest and moist savannah zones of Cameroon.

48. Domestication, genre et vulnérabilité : Participation des femmes, des Jeunes et des catégories les plus pauvres à la domestication des arbres agroforestiers au Cameroun.

49. Land tenure and management in the districts around Mt Elgon: An assessment presented to the Mt Elgon ecosystem conservation programme.

50. The production and marketing of leaf meal from fodder shrubs in Tanga, Tanzania: A pro-poor enterprise for improving livestock productivity.

51. Buyers Perspective on Environmental Services (ES) and Commoditization as an approach to liberate ES markets in the Philippines.

52. Towards Towards community-driven conservation in southwest China: Reconciling state and local perceptions.

53. Biofuels in China: An Analysis of the Opportunities and Challenges of Jatropha curcas in Southwest China.

54. Jatropha curcas biodiesel production in Kenya: Economics and potential value chain development for smallholder farmers

55. Livelihoods and Forest Resources in Aceh and Nias for a Sustainable Forest Resource Management and Economic Progress

56. Agroforestry on the interface of Orangutan Conservation and Sustainable Livelihoods in Batang Toru, North Sumatra.

57. Assessing Hydrological Situation of Kapuas Hulu Basin, Kapuas Hulu Regency, West Kalimantan. 
58. Assessing the Hydrological Situation of Talau Watershed, Belu Regency, East Nusa Tenggara.

59. Kajian Kondisi Hidrologis DAS Talau, Kabupaten Belu, Nusa Tenggara Timur.

60. Kajian Kondisi Hidrologis DAS Kapuas Hulu, Kabupaten Kapuas Hulu, Kalimantan Barat.

61. Lessons learned from community capacity building activities to support agroforest as sustainable economic alternatives in Batang Toru orang utan habitat conservation program (Martini, Endri et al.)

62. Mainstreaming Climate Change in the Philippines.

63. A Conjoint Analysis of Farmer Preferences for Community Forestry Contracts in the Sumber Jaya Watershed, Indonesia.

64. The highlands: a shared water tower in a changing climate and changing Asia

65. Eco-Certification: Can It Deliver Conservation and Development in the Tropics.

66. Designing ecological and biodiversity sampling strategies. Towards mainstreaming climate change in grassland management.

67. Towards mainstreaming climate change in grassland management policies and practices on the Tibetan Plateau

68. An Assessment of the Potential for Carbon Finance in Rangelands

69 ECA Trade-offs Among Ecosystem Services in the Lake Victoria Basin.

69. The last remnants of mega biodiversity in West Java and Banten: an in-depth exploration of RaTA (Rapid Land Tenure Assessment) in Mount Halimun-Salak National Park Indonesia

70. Le business plan d'une petite entreprise rurale de production et de commercialisation des plants des arbres locaux. Cas de quatre pépinières rurales au Cameroun.

71. Les unités de transformation des produits forestiers non ligneux alimentaires au Cameroun. Diagnostic technique et stratégie de développement Honoré Tabuna et Ingratia Kayitavu.

72. Les exportateurs camerounais de safou (Dacryodes edulis) sur le marché sous régional et international. Profil, fonctionnement et stratégies de développement.

73. Impact of the Southeast Asian Network for Agroforestry Education (SEANAFE) on agroforestry education capacity.

74. Setting landscape conservation targets and promoting them through compatible land use in the Philippines.

75. Review of methods for researching multistrata systems.

76. Study on economical viability of Jatropha curcas L. plantations in Northern Tanzania assessing farmers' prospects via cost-benefit analysis

77. Cooperation in Agroforestry between Ministry of Forestry of Indonesia and International Center for Research in Agroforestry

78. "China's bioenergy future. an analysis through the Lens if Yunnan Province

79. Land tenure and agricultural productivity in Africa: A comparative analysis of the economics literature and recent policy strategies and reforms

80. Boundary organizations, objects and agents: linking knowledge with action in Agroforestry watersheds

81. Reducing emissions from deforestation and forest degradation (REDD) in Indonesia: options and challenges for fair and efficient payment distribution mechanisms

\section{9}

82. Mainstreaming climate change into agricultural education: challenges and perspectives

83. Challenging conventional mindsets and disconnects in conservation: the emerging role of ecoagriculture in Kenya's landscape mosaics 
84. Lesson learned RATA garut dan bengkunat: suatu upaya membedah kebijakan pelepasan kawasan hutan dan redistribusi tanah bekas kawasan hutan

85. The emergence of forest land redistribution in Indonesia

86. Commercial opportunities for fruit in Malawi

87. Status of fruit production processing and marketing in Malawi

88. Fraud in tree science

89. Trees on farm: analysis of global extent and geographical patterns of agroforestry

90. The springs of Nyando: water, social organization and livelihoods in Western Kenya

91. Building capacity toward region-wide curriculum and teaching materials development in agroforestry education in Southeast Asia

92. Overview of biomass energy technology in rural Yunnan (Chinese - English abstract)

93. A pro-growth pathway for reducing net GHG emissions in China

94. Analysis of local livelihoods from past to present in the central Kalimantan Ex-Mega Rice Project area

95. Constraints and options to enhancing production of high quality feeds in dairy production in Kenya, Uganda and Rwanda

2010

96. Agroforestry education in the Philippines: status report from the Southeast Asian Network for Agroforestry Education (SEANAFE)

97. Economic viability of Jatropha curcas L. plantations in Northern Tanzania- assessing farmers' prospects via cost-benefit analysis.

98. Hot spot of emission and confusion: land tenure insecurity, contested policies and competing claims in the central Kalimantan Ex-Mega Rice Project area

99. Agroforestry competences and human resources needs in the Philippines

100. CES/COS/CIS paradigms for compensation and rewards to enhance environmental Services

101. Case study approach to region-wide curriculum and teaching materials development in agroforestry education in Southeast Asia

102. Stewardship agreement to reduce emissions from deforestation and degradation (REDD): Lubuk Beringin's Hutan Desa as the first village forest in Indonesia

103. Landscape dynamics over time and space from ecological perspective

104. Komoditisasi atau koinvestasi jasa lingkungan: skema imbal jasa lingkungan program peduli sungai di DAS Way Besai, Lampung, Indonesia

105. Improving smallholders' rubber quality in Lubuk Beringin, Bungo district, Jambi province, Indonesia: an initial analysis of the financial and social benefits

106. Rapid Carbon Stock Appraisal (RACSA) in Kalahan, Nueva Vizcaya, Philippines

107. Tree domestication by ICRAF and partners in the Peruvian Amazon: lessons learned and future prospects in the domain of the Amazon Initiative eco-regional program

108. Memorias del Taller Nacional: “Iniciativas para Reducir la Deforestación en la region Andino Amazónica”, 09 de Abril del 2010. Proyecto REALU Peru

109. Percepciones sobre la Equidad y Eficiencia en la cadena de valor de REDD en Perú -Reporte de Talleres en Ucayali, San Martín y Loreto, 2009. Proyecto REALU-Perú.

110. Reducción de emisiones de todos los Usos del Suelo. Reporte del Proyecto REALU Perú Fase 1

111. Programa Alternativas a la Tumba-y-Quema (ASB) en el Perú. Informe Resumen y Síntesis de la Fase II. 2da. versión revisada

112. Estudio de las cadenas de abastecimiento de germoplasma forestal en la amazonía Boliviana 
113. Biodiesel in the Amazon

114. Estudio de mercado de semillas forestales en la amazonía Colombiana

115. Estudio de las cadenas de abastecimiento de germoplasma forestal en Ecuador http://dx.doi.org10.5716/WP10340.PDF

116. How can systems thinking, social capital and social network analysis help programs achieve impact at scale?

117. Energy policies, forests and local communities in the Ucayali Region, Peruvian Amazon

118. NTFPs as a Source of Livelihood Diversification for Local Communities in the Batang Toru Orangutan Conservation Program

119. Studi Biodiversitas: Apakah agroforestry mampu mengkonservasi keanekaragaman hayati di DAS Konto?

120. Estimasi Karbon Tersimpan di Lahan-lahan Pertanian di DAS Konto, Jawa Timur

121. Implementasi Kaji Cepat Hidrologi (RHA) di Hulu DAS Brantas, Jawa Timur. http://dx.doi.org/10.5716/WP10338.PDF

122. Kaji Cepat Hidrologi di Daerah Aliran Sungai Krueng Peusangan, NAD,Sumatra http://dx.doi.org/10.5716/WP10337.PDF

123. A Study of Rapid Hydrological Appraisal in the Krueng Peusangan Watershed, NAD, Sumatra. http://dx.doi.org/10.5716/WP10339.PDF

\section{1}

124. An Assessment of farm timber value chains in Mt Kenya area, Kenya

125. A Comparative financial analysis of current land use systems and implications for the adoption of improved agroforestry in the East Usambaras, Tanzania

126. Agricultural monitoring and evaluation systems

127. Challenges and opportunities for collaborative landscape governance in the East Usambara Mountains, Tanzania

128. Transforming Knowledge to Enhance Integrated Natural Resource Management Research, Development and Advocacy in the Highlands of Eastern Africa http://dx.doi.org/10.5716/WP11084.PDF

129. Carbon-forestry projects in the Philippines: potential and challenges The Mt Kitanglad Range forestcarbon development http://dx.doi.org10.5716/WP11054.PDF

130. Carbon forestry projects in the Philippines: potential and challenges. The Arakan Forest Corridor forest-carbon project. http://dx.doi.org10.5716/WP11055.PDF

131. Carbon-forestry projects in the Philippines: potential and challenges. The Laguna Lake Development Authority's forest-carbon development project. http://dx.doi.org/10.5716/WP11056.PDF

132. Carbon-forestry projects in the Philippines: potential and challenges. The Quirino forest-carbon development project in Sierra Madre Biodiversity Corridor http://dx.doi.org10.5716/WP11057.PDF

133. Carbon-forestry projects in the Philippines: potential and challenges. The Ikalahan Ancestral Domain forest-carbon development http://dx.doi.org10.5716/WP11058.PDF

134. The Importance of Local Traditional Institutions in the Management of Natural Resources in the Highlands of Eastern Africa. http://dx.doi.org/10.5716/WP11085.PDF

135. Socio-economic assessment of irrigation pilot projects in Rwanda. http://dx.doi.org/10.5716/WP11086.PDF

136. Performance of three rambutan varieties (Nephelium lappaceum L.) on various nursery media. http://dx.doi.org/10.5716/WP11232.PDF 
137. Climate change adaptation and social protection in agroforestry systems: enhancing adaptive capacity and minimizing risk of drought in Zambia and Honduras http://dx.doi.org/10.5716/WP11269.PDF

138. Does value chain development contribute to rural poverty reduction? Evidence of asset building by smallholder coffee producers in Nicaragua http://dx.doi.org/10.5716/WP11271.PDF

139. Potential for biofuel feedstock in Kenya. http://dx.doi.org/10.5716/WP11272.PDF

140. Impact of fertilizer trees on maize production and food security in six districts of Malawi. http://dx.doi.org/10.5716/WP11281.PDF

\section{2}

141. Fortalecimiento de capacidades para la gestión del Santuario Nacional Pampa Hermosa:

Construyendo las bases para un manejo adaptativo para el desarrollo local. Memorias del Proyecto. http://dx.doi.org/10.5716/WP12005.PDF

142. Understanding rural institutional strengthening: A cross-level policy and institutional framework for sustainable development in Kenya http://dx.doi.org/10.5716/WP12012.PDF

143. Climate change vulnerability of agroforestry http://dx.doi.org/10.5716/WP16722.PDF

144. Rapid assesment of the inner Niger delta of Mali http://dx.doi.org/10.5716/WP12021.PDF

145. Designing an incentive program to reduce on-farm deforestationin the East Usambara Mountains, Tanzania http://dx.doi.org/10.5716/WP12048.PDF

146. Extent of adoption of conservation agriculture and agroforestry in Africa: the case of Tanzania, Kenya, Ghana, and Zambia http://dx.doi.org/10.5716/WP12049.PDF

147. Policy incentives for scaling up conservation agriculture with trees in Africa: the case of Tanzania, Kenya, Ghana and Zambia http://dx.doi.org/10.5716/WP12050.PDF

148. Commoditized or co-invested environmental services? Rewards for environmental services scheme: River Care program Way Besai watershed, Lampung, Indonesia. http://dx.doi.org/10.5716/WP12051.PDF

149. Assessment of the headwaters of the Blue Nile in Ethiopia. http://dx.doi.org/10.5716/WP12160.PDF

150. Assessment of the uThukela Watershed, Kwazaulu. http://dx.doi.org/10.5716/WP12161.PDF

151. Assessment of the Oum Zessar Watershed of Tunisia. http://dx.doi.org/10.5716/WP12162.PDF

152. Assessment of the Ruwenzori Mountains in Uganda. http://dx.doi.org/10.5716/WP12163.PDF

153. History of agroforestry research and development in Viet Nam. Analysis of research opportunities and gaps. http://dx.doi.org/10.5716/WP12052.PDF

154. REDD+ in Indonesia: a Historical Perspective. http://dx.doi.org/10.5716/WP12053.PDF

155. Agroforestry and Forestry in Sulawesi series: Livelihood strategies and land use system dynamics in South Sulawesi http://dx.doi.org/10.5716/WP12054.PDF

156. Agroforestry and Forestry in Sulawesi series: Livelihood strategies and land use system dynamics in Southeast Sulawesi. http://dx.doi.org/10.5716/WP12055.PDF

157. Agroforestry and Forestry in Sulawesi series: Profitability and land-use systems in South and Southeast Sulawesi. http://dx.doi.org/10.5716/WP12056.PDF

158. Agroforestry and Forestry in Sulawesi series: Gender, livelihoods and land in South and Southeast Sulawesi http://dx.doi.org/10.5716/WP12057.PDF

159. Agroforestry and Forestry in Sulawesi series: Agroforestry extension needs at the community level in AgFor project sites in South and Southeast Sulawesi, Indonesia. http://dx.doi.org/10.5716/WP12058.PDF

160. Agroforestry and Forestry in Sulawesi series: Rapid market appraisal of agricultural, plantation and forestry commodities in South and Southeast Sulawesi. http://dx.doi.org/10.5716/WP12059.PDF 


\section{3}

161. Diagnosis of farming systems in the Agroforestry for Livelihoods of Smallholder farmers in Northwestern Viet Nam project http://dx.doi.org/10.5716/WP13033.PDF

162. Ecosystem vulnerability to climate change: a literature review. http://dx.doi.org/10.5716/WP13034.PDF

163. Local capacity for implementing payments for environmental services schemes: lessons from the RUPES project in northeastern Viet Nam http://dx.doi.org/10.5716/WP13046.PDF

164. Seri Agroforestri dan Kehutanan di Sulawesi: Agroforestry dan Kehutanan di Sulawesi: Strategi mata pencaharian dan dinamika sistem penggunaan lahan di Sulawesi Selatan http://dx.doi.org/10.5716/WP13040.PDF

165. Seri Agroforestri dan Kehutanan di Sulawesi: Mata pencaharian dan dinamika sistem penggunaan lahan di Sulawesi Tenggara http://dx.doi.org/10.5716/WP13041.PDF

166. Seri Agroforestri dan Kehutanan di Sulawesi: Profitabilitas sistem penggunaan lahan di Sulawesi Selatan dan Sulawesi Tenggara http://dx.doi.org/10.5716/WP13042.PDF

167. Seri Agroforestri dan Kehutanan di Sulawesi: Gender, mata pencarian dan lahan di Sulawesi Selatan dan Sulawesi Tenggara http://dx.doi.org/10.5716/WP13043.PDF

168. Seri Agroforestri dan Kehutanan di Sulawesi: Kebutuhan penyuluhan agroforestri pada tingkat masyarakat di lokasi proyek AgFor di Sulawesi Selatan dan Tenggara, Indonesia. http://dx.doi.org/10.5716/WP13044.PDF

169. Seri Agroforestri dan Kehutanan di Sulawesi: Laporan hasil penilaian cepat untuk komoditas pertanian, perkebunan dan kehutanan di Sulawesi Selatan dan Tenggara http://dx.doi.org/10.5716/WP13045.PDF

170. Agroforestry, food and nutritional security http://dx.doi.org/10.5716/WP13054.PDF

171. Stakeholder Preferences over Rewards for Ecosystem Services: Implications for a REDD+ Benefit Distribution System in Viet Nam http://dx.doi.org/10.5716/WP13057.PDF

172. Payments for ecosystem services schemes: project-level insights on benefits for ecosystems and the rural poor http://dx.doi.org/10.5716/WP13001.PDF

173. Good practices for smallholder teak plantations: keys to success http://dx.doi.org/10.5716/WP13246.PDF

174. Market analysis of selected agroforestry products in the Vision for Change Project intervention Zone, Côte d'Ivoire http://dx.doi.org/10.5716/WP13249.PDF

175. Rattan futures in Katingan: why do smallholders abandon or keep their gardens in Indonesia's 'rattan district'? http://dx.doi.org/10.5716/WP13251.PDF

176. Management along a gradient: the case of Southeast Sulawesi's cacao production landscapes http://dx.doi.org/10.5716/WP13265.PDF

\section{4}

177. Are trees buffering ecosystems and livelihoods in agricultural landscapes of the Lower Mekong Basin? Consequences for climate-change adaptation. http://dx.doi.org/10.5716/WP14047.PDF

178. Agroforestry, livestock, fodder production and climate change adaptation and mitigation in East Africa: issues and options. http://dx.doi.org/10.5716/WP14050.PDF

179. Trees on farms: an update and reanalysis of agroforestry's global extent and socio-ecological characteristics. http://dx.doi.org/10.5716/WP14064.PDF

180. Beyond reforestation: an assessment of Vietnam's REDD+ readiness. http://dx.doi.org/10.5716/WP14097.PDF 
181. Farmer-to-farmer extension in Kenya: the perspectives of organizations using the approach. http://dx.doi.org/10.5716/WP14380.PDF

182. Farmer-to-farmer extension in Cameroon: a survey of extension organizations. http://dx.doi.org/10.5716/WP14383.PDF

183. Farmer-to-farmer extension approach in Malawi: a survey of organizations: a survey of organizations http://dx.doi.org/10.5716/WP14391.PDF

184. Seri Agroforestri dan Kehutanan di Sulawesi: Kuantifikasi jasa lingkungan air dan karbon pola agroforestri pada hutan rakyat di wilayah sungai Jeneberang

185. Options for Climate-Smart Agriculture at Kaptumo Site in Kenyahttp://dx.doi.org/10.5716/WP14394.PDF

\section{5}

186. Agroforestry for Landscape Restoration and Livelihood Development in Central Asia http://dx.doi.org/10.5716/WP14143.PDF

187. "Projected Climate Change and Impact on Bioclimatic Conditions in the Central and South-Central Asia Region" http://dx.doi.org/10.5716/WP14144.PDF

188. Land Cover Changes, Forest Loss and Degradation in Kutai Barat, Indonesia. http://dx.doi.org/10.5716/WP14145.PDF

189. The Farmer-to-Farmer Extension Approach in Malawi: A Survey of Lead Farmers. http://dx.doi.org/10.5716/WP14152.PDF

190. Evaluating indicators of land degradation and targeting agroforestry interventions in smallholder farming systems in Ethiopia. http://dx.doi.org/10.5716/WP14252.PDF

191. Land health surveillance for identifying land constraints and targeting land management options in smallholder farming systems in Western Cameroon

192. Land health surveillance in four agroecologies in Malawi

193. Cocoa Land Health Surveillance: an evidence-based approach to sustainable management of cocoa landscapes in the Nawa region, South-West Côte d'Ivoire http://dx.doi.org/10.5716/WP14255.PDF

194. Situational analysis report: Xishuangbanna autonomous Dai Prefecture, Yunnan Province, China. http://dx.doi.org/10.5716/WP14255.PDF

195. Farmer-to-farmer extension: a survey of lead farmers in Cameroon. http://dx.doi.org/10.5716/WP15009.PDF

196. From transition fuel to viable energy source Improving sustainability in the sub-Saharan charcoal sector http://dx.doi.org/10.5716/WP15011.PDF

197. Mobilizing Hybrid Knowledge for More Effective Water Governance in the Asian Highlands http://dx.doi.org/10.5716/WP15012.PDF

198. Water Governance in the Asian Highlands http://dx.doi.org/10.5716/WP15013.PDF

199. Assessing the Effectiveness of the Volunteer Farmer Trainer Approach in Dissemination of Livestock Feed Technologies in Kenya vis-à-vis other Information Sources http://dx.doi.org/10.5716/WP15022.PDF

200. The rooted pedon in a dynamic multifunctional landscape: Soil science at the World Agroforestry Centre http://dx.doi.org/10.5716/WP15023.PDF

201. Characterising agro-ecological zones with local knowledge. Case study: Huong Khe district, Ha Tinh, Viet Nam http://dx.doi.org/10.5716/WP15050.PDF

202. Looking back to look ahead: Insight into the effectiveness and efficiency of selected advisory approaches in the dissemination of agricultural technologies indicative of Conservation Agriculture with Trees in Machakos County, Kenya. http://dx.doi.org/10.5716/WP15065.PDF

203. Pro-poor Biocarbon Projects in Eastern Africa Economic and Institutional Lessons. http://dx.doi.org/10.5716/WP15022.PDF 
204. Projected climate change impacts on climatic suitability and geographical distribution of banana and coffee plantations in Nepal. http://dx.doi.org/10.5716/WP15294.PDF

205. Agroforestry and Forestry in Sulawesi series: Smallholders' coffee production and marketing in Indonesia. A case study of two villages in South Sulawesi Province. http://dx.doi.org/10.5716/WP15690.PDF

206. Mobile phone ownership and use of short message service by farmer trainers: a case study of Olkalou and Kaptumo in Kenya http://dx.doi.org/10.5716/WP15691.PDF

207. Associating multivariate climatic descriptors with cereal yields: a case study of Southern Burkina Faso http://dx.doi.org/10.5716/WP15273.PDF

208. Preferences and adoption of livestock feed practices among farmers in dairy management groups in Kenya http://dx.doi.org/10.5716/WP15675.PDF

209. Scaling up climate-smart agriculture: lessons learned from South Asia and pathways for success http://dx.doi.org/10.5716/WP15720.PDF

210. Agroforestry and Forestry in Sulawesi series: Local perceptions of forest ecosystem services and collaborative formulation of reward mechanisms in South and Southeast Sulawesi http://dx.doi.org/10.5716/WP15721.PDF

211. Potential and challenges in implementing the co-investment of ecosystem services scheme in Buol District, Indonesia. http://dx.doi.org/10.5716/WP15722.PDF

212. Tree diversity and its utilization by the local community in Buol District, Indonesia http://dx.doi.org/10.5716/WP15723.PDF

213 Vulnerability of smallholder farmers and their preferences on farming practices in Buol District, Indonesia http://dx.doi.org/10.5716/WP15724.PDF

214. Dynamics of Land Use/Cover Change and Carbon Emission in Buol District, Indonesia http://dx.doi.org/10.5716/WP15725.PDF 


The World Agroforestry Centre is an autonomous, non-profit research organization whose vision is a rural transformation in the developing world as smallholder households increase their use of trees in agricultural landscapes to improve food security, nutrition, income, health, shelter, social cohesion, energy resources and environmental sustainability. The Centre generates science-based knowledge about the diverse roles that trees play in agricultural landscapes, and uses its research to advance policies and practices, and their implementation that benefit the poor and the environment. It aims to ensure that all this is achieved by enhancing the quality of its science work, increasing operational efficiency, building and maintaining strong partnerships, accelerating the use and impact of its research, and promoting greater cohesion, interdependence and alignment within the organization.

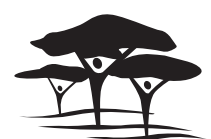

United Nations Avenue, Gigiri • PO Box 30677 • Nairobi, $00100 \cdot$ Kenya Telephone: +254 207224000 or via USA +1 6508336645 Fax: +254207224001 or via USA +1 6508336646

Email: worldagroforestry@cgiar.org•www.worldagroforestry.org

Southeast Asia Regional Program • Sindang Barang • Bogor 16680

PO Box $161 \cdot$ Bogor $16001 \cdot$ Indonesia

Telephone: +62 2518625415 • Fax: +62 2518625416

- Email: icraf-indonesia@cgiar.org

www.worldagroforestry.org/regions/southeast_asia

blog.worldagroforestry.org 